\title{
Assembly of a Functional HCV Glycoprotein Heterodimer
}

\author{
Muriel Lavie, Anne Goffard, and Jean \\ Dubuisson*
}

Institut de Biologie de Lille (UMR8161), CNRS, Université de Lille I and II, and Institut Pasteur de Lille, Lille, France

\begin{abstract}
The two HCV envelope glycoproteins E1 and E2 are released from $\mathrm{HCV}$ polyprotein by signal peptidase cleavages. These glycoproteins are type I transmembrane proteins with a highly glycosylated $\mathrm{N}$-terminal ectodomain and a C-terminal hydrophobic anchor. After their synthesis, HCV glycoproteins E1 and E2 associate as a noncovalent heterodimer. The transmembrane domains of HCV envelope glycoproteins play a major role in E1E2 heterodimer assembly and subcellular localization. The envelope glycoprotein complex E1E2 has been proposed to be essential for HCV entry. However, for a long time, HCV entry studies have remained limited because of the lack of a robust cell culture system to amplify this virus. A few years ago, a model mimicking the entry process of HCV lifecycle has been developed by pseudotyping retroviral particles with native $\mathrm{HCV}$ envelope glycoproteins. This model allowed the characterization of functional E1E2 envelope glycoproteins. The data obtained can now be confirmed with the help of a newly developed cellculture system that allows efficient amplification of $\mathrm{HCV}$ $(\mathrm{HCV} c \mathrm{c})$. Here, we present the recent data that have been accumulated on the assembly of the functional HCV glycoprotein heterodimer.
\end{abstract}

\section{Introduction}

As obligate intracellular parasites, all viruses must have ways of entering target cells to initiate replication and infection. The first step in virus entry is the recognition of host cells through cell surface receptor(s). This initial engagement can both mediate attachment and act as a primer for subsequent conformational alteration, leading to virus entry into host cell. In many cases, interaction with a receptor is important for defining the tropism of a virus for a particular organism, tissue or cell type. Enveloped viruses possess a lipid bilayer that surrounds their nucleocapsid. The glycoproteins present in their envelope are involved in the receptor-binding step. After attachment, the entry of these viruses into cells requires the fusion of the viral and a cellular membrane by a process that is also driven by the viral envelope glycoproteins. To fulfill these functions, viral envelope glycoproteins have to adopt dramatically different conformations during the virus lifecycle. In addition, these conformational changes have to occur at a precise time of the virus lifecycle and have thus to be tightly controlled.

*For correspondence: jean.dubuisson@ibl.fr
$\mathrm{HCV}$ encodes two envelope glycoproteins, called E1 and E2. For a long time, the lack of a cell culture system supporting efficient $\mathrm{HCV}$ replication and particle assembly has hampered the characterization of the envelope proteins present on the virion. Cell culture transient expression systems have allowed the characterization of the first steps in the biogenesis of HCV envelope glycoproteins (reviewed in Op De Beeck et al., 2001). In addition, surrogate models have also been developed to study the entry steps of HCV lifecycle (reviewed in Op De Beeck and Dubuisson, 2003). Among them, HCVpp has been developed by pseudotyping retroviral particles with native $\mathrm{HCV}$ envelope glycoproteins and has allowed to characterize the assembly of functional HCV envelope glycoproteins (Bartosch et al., 2003b; Drummer et al., 2003; Hsu et al., 2003). More recently, the development of a cell-culture system that allows a relatively efficient amplification of HCV permits to confirm the data previously obtained and to study the role played by the envelope proteins during the whole life cycle of HCV (Lindenbach and Rice, 2005; Wakita et al., 2005; Zhong et al., 2005).

\section{Biogenesis of HCV envelope glycoproteins}

Cleavage of HCV glycoproteins from the polyprotein As for the other members of the Flaviviridae family the genome of HCV encodes a single polyprotein. This $\sim 3010$ amino acid polyprotein is processed by cellular (signal peptidase and signal peptide peptidase) and viral proteases (NS2-3 and NS3-4A) to generate at least 10 polypeptides (reviewed in Penin et al., 2004). The nonstructural proteins are released from the polyprotein after cleavage by HCV proteases NS2-3 and NS3-4A, whereas the structural proteins are released by host endoplasmic reticulum (ER) signal peptidase(s) (Fig. 1) (reviewed in Reed and Rice, 2000). Further processing mediated by a signal peptide peptidase also occurs at the C-terminus of the capsid protein (McLauchlan et al., 2002). Although most cleavages in the polyprotein precursor proceed to completion during or immediately after translation, partial cleavages at the E2/p7 and p7/ NS2 sites lead to the production of an uncleaved E2p7NS2 molecule (Dubuisson et al., 1994; Dubuisson and Rice, 1996; Grakoui et al., 1993; Lin et al., 1994; Mizushima et al., 1994). Most of NS2 is progressively cleaved from the E2p7NS2 precursor, whereas at least for most HCV strains analyzed, the cleavage between E2 and $p 7$ does not change over time (Dubuisson, 2000). This leads to the production of E2, E2p7, p7 and NS2.

The sequences located immediately $\mathrm{N}$-terminally of E2/p7 and p7/NS2 cleavage sites can efficiently function as signal peptides Indeed, when fused to a reporter protein, the signal peptides of $p 7$ and NS2 are efficiently cleaved (Carrère-Kremer et al., 2004). These data indicate that inefficiency of cleavage at E2/p7 and p7/NS2 sites is 


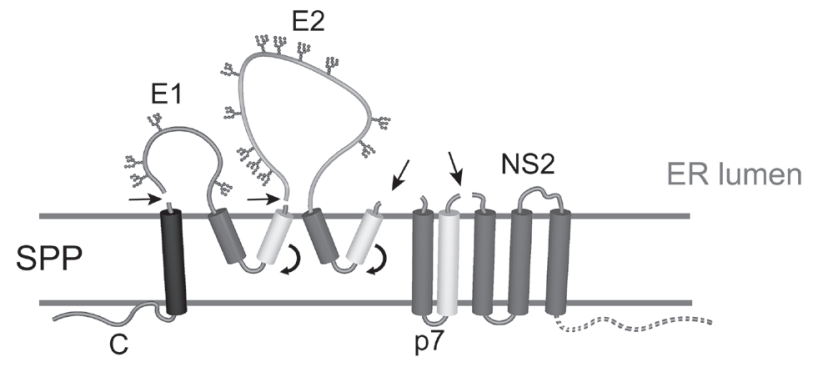

Fig. 1. Processing of the N-terminal one-third of HCV polyprotein. The arrows show host signal peptidase cleavages. Partial cleavages at E2/p7 and $\mathrm{p} 7 / \mathrm{NS} 2$ sites are indicated by dotted arrows. Cleavage by the host cell signal peptide peptidase (SPP) is indicated by scissors. The signal peptide and signals of reinitiation of translocation are shown as a black cylinder and light grey cylinders, respectively. The transmembrane domains of HCV envelope glycoproteins are represented in their pre-cleavage topology. Post-cleavage reorientation of the glycoprotein signals of reinitiation of translocation is indicated curved arrows.

not due to the presence of suboptimal signal peptides. The p7 polypeptide is a polytopic membrane protein containing two transmembrane domains with both its $\mathrm{N}$ - and C-termini oriented toward the ER lumen (Fig. 1) (Carrère-Kremer et al., 2002). Interestingly, the presence of the first transmembrane domain of $p 7$ reduces the efficiency of p7/NS2 cleavage (Carrère-Kremer et al., 2004). Sequence analyses and mutagenesis studies have also identified structural determinants responsible for the partial cleavage at both E2/p7 and p7/NS2 sites (CarrèreKremer et al., 2004). In addition, the short distance between the cleavage site of E2/p7 or p7/NS2 and the predicted transmembrane $\alpha$-helix located downstream of the cleavage sites might impose additional structural constraints to these cleavage sites (Fig. 1). Such constraints in the processing of a polyprotein precursor are likely essential for $\mathrm{HCV}$ to post-translationally regulate the kinetics and/or the level of expression of p7 as well as NS2 and E2 mature proteins.

The processing at the E2p7 site has been further explored. It has been reported to be more efficient in genotype $1 \mathrm{~b}$ (strain $\mathrm{BK}$ ) than in the genotype 1a (strain H77c) (Dubuisson et al., 1994; Lin et al., 1994). A sequence comparison of $\mathrm{p} 7$ signal peptides of these two viral strains has identified a difference of three amino acids and mutational analysis has shown that the V720L change in the $\mathrm{H} 77 \mathrm{c}$ sequence substantially increases the efficiency of processing at the E2/p7 site (Isherwood and Patel, 2005). Although, when expressed alone, p7 protein has been shown to adopt a double membrane spanning topology with both extremities orientated luminally in the ER (Carrère-Kremer et al., 2002), the C-terminal part of E2p7 proteins has been found to be located in the cytosol (Isherwood and Patel, 2005). These data suggest that p7 can potentially adopt a dual transmembrane topology. It remains however to be shown whether an E2p7 with a cytosolic orientation of the C-terminus of $p 7$ exists when this protein is expressed in the context of the polyprotein.

Since p7 and NS2 are not essential for HCV genomic replication (Blight et al., 2000; Lohmann et al., 1999), they will likely play their role in virion assembly, a process that is supposed to be tightly regulated. It has recently been shown that $p 7$ reconstituted into artificial lipid membranes homo-oligomerizes and behaves as an ion channel protein (Griffin et al., 2003; Griffin et al., 2004; Pavlovic et al., 2003; Premkumar et al., 2004). It is likely that, when bound to E2, p7 cannot oligomerize and function as an ion channel, and the existence of E2p7 would therefore reduce the amount of functional $p 7$ molecules available. Production of precursors like E2p7NS2 and E2p7 might be a means to maintain $p 7$ inactive during the phase of the accumulation of E2 molecules required for HCV envelope formation. Alternatively, such precursors might also control the temporal release of E2 and NS2.

\section{Glycosylation of HCV envelope glycoproteins}

$\mathrm{N}$-linked glycosylation is one of the most common types of protein modification, and it occurs by the transfer of an oligosaccharide from a lipid intermediate to an Asn residue in the consensus sequence Asn-X-Thr/Ser of a nascent protein, where $X$ is any amino acid except Pro (Gavel and von Heijne, 1990; Kornfeld and Kornfeld, 1985). The addition of this glycan is catalyzed by the oligosaccharyltransferase, which is closely associated with the translocon through which the nascent peptidic chains emerge in the ER lumen (Silberstein and Gilmore, 1996). However, not every tripeptide sequence in a protein sequence is used for carbohydrate addition (Gavel and von Heijne, 1990). In the early secretory pathway, the glycans play a role in protein folding, quality control and certain sorting events. Viral envelope proteins usually contain $\mathrm{N}$ linked glycans that can play a major role in their folding, in their entry functions or in modulating the immune response (Hebert et al., 1997; Ohuchi et al., 1997a; Ohuchi et al., 1997b; van Kooyk and Geijtenbeek, 2003; von Messling and Cattaneo, 2003; Wei et al., 2003).

The ectodomains of HCV envelope glycoproteins E1 and E2 are highly modified by $\mathrm{N}$-linked glycans. E1 and E2 possess up to 6 and 11 potential glycosylation sites, respectively (Fig. 2). Sequence analyses of E1 indicate that five potential $\mathrm{N}$-glycosylation sites are strongly conserved among HCV genotypes (Goffard and Dubuisson, 2003; Zhang et al., 2004b). However in one case the presence of a proline residue immediately downstream the glycosylation site is unfavorable for glycosylation, and it has been confirmed experimentally that this site is not glycosylated (Meunier et al., 1999). Interestingly, the glycosylation site of E1 at position 250 is poorly conserved; this site is indeed only observed in genotypes 1b and 6 (Fig. 2) (Goffard and Dubuisson, 2003). Most E2 glycosylation sites are also well conserved. Indeed, global sequence analyses of potential glycosylation sites in E2 indicate that 9 of the 11 sites are strongly conserved (Goffard and Dubuisson, 2003; Zhang et al., 2004b). The two remaining sites, N5 and N7, show conservation levels of $75 \%$ and $89 \%$, respectively (Goffard and Dubuisson, 2003).

Mutants of E1 and E2 have been produced to characterize the glycosylation of these proteins (Goffard et al., 2005; Meunier et al., 1999; Nakano et al., 1999; Slater-Handshy et al., 2004). In the context of the $\mathrm{H}$ strain, the four potential glycosylation sites were shown to be occupied by glycans (Goffard et al., 2005; Meunier et al., 1999). In the case of E2, a first study has shown that mutation of some glycosylation sites in the context 


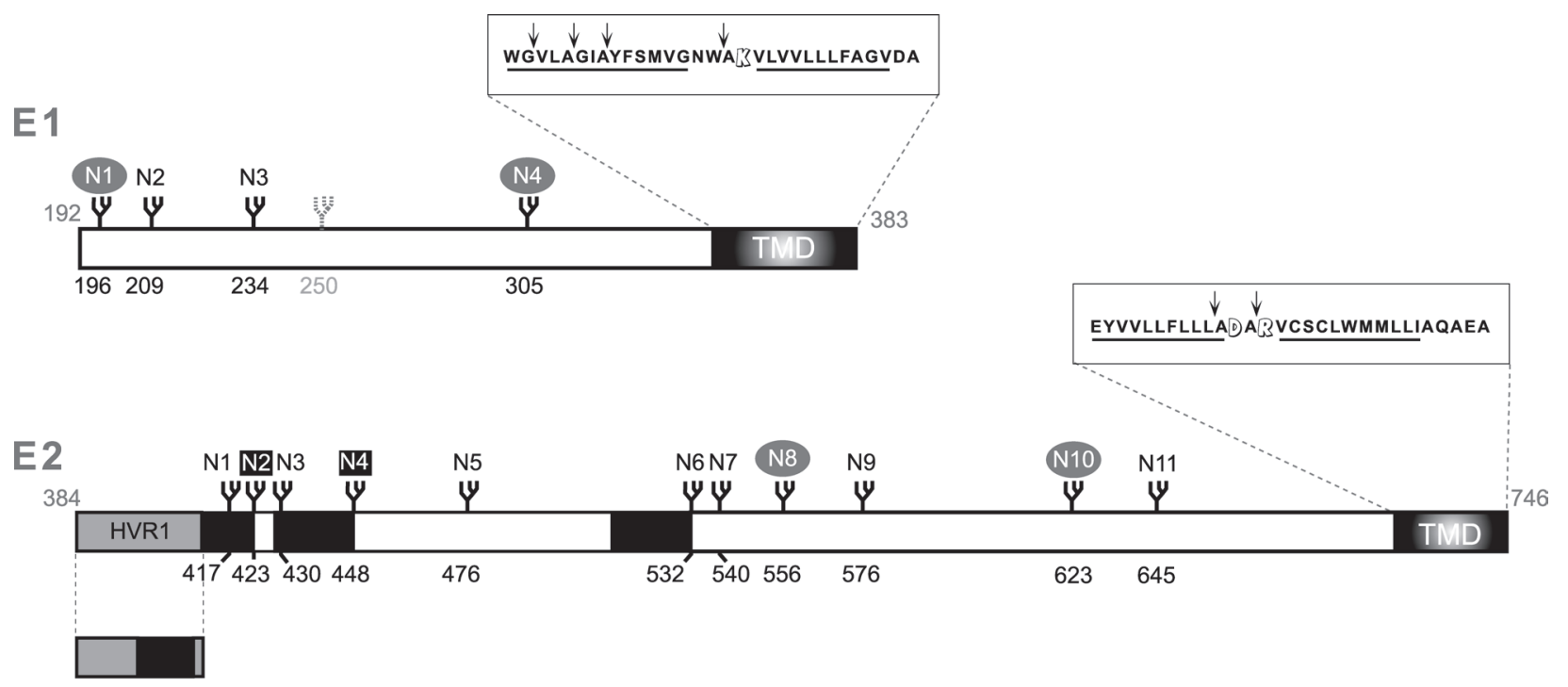

Fig. 2. Schematic representation of E1 and E2 features. Positions of $\mathrm{N}$-linked glycans are indicated as an $\mathrm{N}$ followed by a number related to the relative position of the potential glycosylation site in each glycoprotein. The numbers correspond to the positions in the polyprotein of reference strain $\mathrm{H}$ (acc. Number AF009606). Glycans involved in HCVpp entry are indicated with a black square (Goffard et al., 2005). Glycosylations sites for which the mutation alters E1E2 folding are indicated with a grey circle (Goffard et al., 2005). The hypervariable region 1 (HVR1) of E2 is shown as a grey box. The black boxes correspond to E2 epitopes recognized by neutralizing antibodies (Hsu et al., 2003). The sequences of the transmembrane domains of HCV envelope glycoproteins are indicated above their corresponding region in E1 and E2. The two hydrophobic segments in these regions are underlined. The charged residues present between the two hydrophobic stretches are in white lettering. Arrows indicate the positions of inserted alanine residues that disrupt HCV E1E2 heterodimerization (Op De Beeck et al., 2000).

of a truncated form of E2 alters the recognition by sera from HCV patients (Nakano et al., 1999); however, these mutants were not characterized in terms of glycosylation and no clear conclusion can be drawn from this study. More recently, glycosylation mutants have been produced in the context of a truncated form of E2 ending at position 660 (Slater-Handshy et al., 2004). The E2 sequence of $\mathrm{HCV}$ isolate used in this study contains 10 instead of 11 potential glycosylation sites, the site N5 at position 476 being missing (Fig. 2). Interestingly, the last two glycosylation sites, N10 and N11, were not occupied in E2 ${ }_{660}$ (Slater-Handshy et al., 2004). However, at least one of these sites was occupied in the context of full-length E2. A more recent mutagenesis study, in the context of an E2 glycoprotein containing 11 potential glycosylation sites, has shown that all the sites are occupied by glycans (Goffard et al., 2005). In this case, E2 was expressed as a polyprotein containing full-length E1 and E2. Altogether, these data indicate that full-length and truncated forms of E2 can have different properties.

The addition of the glycan precursor is catalyzed by the oligosaccharyltransferase, and this enzyme is thought to have access only to nascent chains as they emerge from the ribosome at the luminal face of the rough ER (Silberstein and Gilmore, 1996). The glycosylation process of $\mathrm{HCV}$ envelope glycoprotein $\mathrm{E} 1$ has been analyzed in the context of a Man-P-Dol-deficient cell line (B3F7) and it has been shown to occur post-translationally (Duvet et al., 2002), indicating that the oligosaccharyltransferase has also access to the E1 glycoprotein for more than an hour after its translation. A characterization of HCV glycoprotein E1 has also shown that, in the absence of E2, different glycoforms of E1 are produced and the glycosylation of E1 is improved by co-expression of E2 in cis (Dubuisson et al., 2000).

\section{Folding of HCV envelope glycoproteins}

HCV envelope glycoproteins have been shown to assemble as a noncovalent E1E2 heterodimer (Deleersnyder et al., 1997). However, at least in heterologous expression systems, HCV envelope glycoproteins have a tendency to also form misfolded aggregates stabilized by disulfide bonds (reviewed in Dubuisson, 2000). Analyses of HCV envelope glycoproteins with conformation-sensitive antibodies are therefore necessary to discriminate noncovalent heterodimers from misfolded complexes (Cocquerel et al., 2003b; Deleersnyder et al., 1997). Alternatively, such discrimination can also be made by analyzing disulfide-bond formation by migrating $\mathrm{HCV}$ envelope glycoproteins on SDS-PAGE under nonreducing conditions (Brazzoli et al., 2005; Dubuisson and Rice, 1996). Analyses of the formation of conformationdependent epitopes and disulfide-bond formation indicate that folding of $\mathrm{HCV}$ envelope glycoproteins is a slow process (Brazzoli et al., 2005; Deleersnyder et al., 1997; Dubuisson and Rice, 1996; Duvet et al., 1998). Interestingly, the folding of E1 has been shown to be dependent on the co-expression of E2 (Michalak et al., 1997; Patel et al., 2001). In addition, it has also been shown that the folding of E2 is also dependent on the co-expression of E1 (Brazzoli et al., 2005; Cocquerel et al., 2003a). Altogether, these observations indicate that $\mathrm{HCV}$ envelope glycoproteins cooperate for the formation of a functional complex. These observations also indicate that, although some degree of folding can be observed in E2 expressed alone (Cocquerel et al., 2003a; Michalak et al., 1997), both glycoproteins need to be co-expressed to analyze their functional properties.

During their folding, HCV envelope glycoproteins have been shown to interact with calnexin (Brazzoli et al., 2005; Choukhi et al., 1998; Dubuisson and Rice, 
1996; Merola et al., 2001), a lectin-like ER chaperone, which shows an affinity for monoglucosylated $\mathrm{N}$-linked oligosaccharides (Trombetta and Helenius, 1998). Both E1 and E2 have been found to associate rapidly with calnexin and dissociate slowly, suggesting a role of this chaperone in the folding of $\mathrm{HCV}$ envelope glycoproteins (Choukhi et al., 1998; Dubuisson and Rice, 1996; Merola et al., 2001). However, more recent data suggest that only E1 interacts with calnexin (Brazzoli et al., 2005). Differences in the cell lines used and/or in the levels of expression of the envelope glycoproteins might potentially explain these discrepancies. Further experiments in cell cultures infected with native HCV particles will be needed to confirm the involvement of calnexin in the folding E2.

The presence of glycans on $\mathrm{HCV}$ envelope glycoproteins can potentially affect their folding either directly or through interaction with calnexin. Site-directed mutagenesis studies have indeed shown that the absence of some glycans in E1 (N1 and N4) and E2 (N8 and N10) leads to misfolding of HCV envelope glycoproteins (Fig. 2) (Goffard et al., 2005; Meunier et al., 1999). This alteration in folding was not due to the lack of interaction of HCV envelope glycoproteins with calnexin, suggesting that the mutations would rather have a direct effect on protein folding. The presence of a large polar saccharide is indeed known to affect the folding at least locally by orienting polypeptide segments toward the surface of protein domains (Imperiali and O'Connor, 1999; Wormald and Dwek, 1999).

\section{Involvement of the transmembrane domains in the biogenesis of E1E2 heterodimer}

\section{Membrane anchor and signal sequence}

Due to their resistance to alkaline or salt extraction, HCV envelope glycoproteins have been confirmed to be membrane associated proteins (Cocquerel et al., 2001; Ralston et al., 1993). In addition, deletion of the C-terminal hydrophobic regions of these proteins leads to their secretion, indicating that these regions are involved in membrane anchoring (Michalak et al., 1997). Sequence analysis of a large number of $\mathrm{HCV}$ isolates has shown that the C-termini of E1 and E2 contain hydrophobic sequences that are less than 30 amino acid residues long (Fig. 2) (Cocquerel et al., 2000). As in other viruses of the Flaviviridae family, these regions are composed of two stretches of hydrophobic residues separated by a short segment containing at least one fully conserved positively charged residue (Cocquerel et al., 2000). Interestingly, when fused to a reporter protein the second hydrophobic stretch functions as a signal sequence (Cocquerel et al., 2002), which is in agreement with the observation that $\mathrm{HCV}$ envelope glycoproteins are released from the polyprotein precursor after cleavage by host signal peptidase(s) (Dubuisson et al., 2002). It is worth noting that in the context of HCV polyprotein, only the sequence located at the C-terminus of the immature form of the capsid protein is a true signal peptide that will interact with the signal recognition particle (Santolini et al., 1994). The sequences present at the C-terminus of E1 and E2 do not interact with the signal recognition particle, and they should be called signals of reinitiation of translocation
(Fig. 1). Deletion of these signals leads to the secretion of $\mathrm{E} 1$ and $E 2$, indicating that these signals are involved in their membrane anchoring (Cocquerel et al., 2000).

\section{ER retention function}

$\mathrm{HCV}$ envelope glycoproteins are retained in the ER (Deleersnyder et al., 1997; Dubuisson et al., 1994; Duvet et al., 1998), and ER retention signals are present in the transmembrane domains of E1 and E2 (Cocquerel et al., 1999; Cocquerel et al., 1998). In addition, the charged residues of the transmembrane domains of E1 (Lys) and E2 (Asp and Arg) play a key role in the ER retention of these glycoproteins (Cocquerel et al., 2000). It has been proposed that an additional ER retention signal might also be present in the ectodomain of E1 (Mottola et al., 2000). Interestingly, in some conditions of overexpression a small fraction of HCV envelope glycoproteins has been shown to accumulate at the plasma membrane (Bartosch et al., 2003b; Drummer et al., 2003; Hsu et al., 2003; Op De Beeck et al., 2004). Cell surface expression of E1 and E2 is likely due to the accumulation of small amounts of glycoproteins escaping the ER-retention machinery, due to saturation of this mechanism. Importantly, the retention of E1E2 in the ER has been confirmed in HCVcc infected cells (Rouillé et al., 2006).

\section{Role in heterodimerization}

In addition to their anchoring, signal sequence and ER retention functions, the transmembrane domains of $\mathrm{HCV}$ envelope glycoproteins have also been shown to play a major role in the assembly of E1E2 heterodimer. Indeed, deletion of the transmembrane domain of E2 or its replacement by the anchor signal of another protein abolishes the formation of E1E2 heterodimer (Cocquerel et al., 1998; Michalak et al., 1997; Patel et al., 2001; Selby et al., 1994). Other studies by site-directed mutagenesis or alanine scanning insertion mutagenesis (Ciczora et al., 2005; Cocquerel et al., 2000; Op De Beeck et al., 2000) have confirmed that the transmembrane domains of E1 and E2 play a direct role in E1E2 assembly. In addition, alanine scanning insertion mutagenesis allowed to identify two distinct segments in the transmembrane domain of $\mathrm{E} 1$ and one in the transmembrane domain of E2 that were specifically involved in E1E2 assembly (Fig. 2). Interestingly, at least one region located outside of the transmembrane domains has also been shown to be involved in heterodimerization (Drummer and Poumbourios, 2004).

\section{Topological change in the transmembrane domain of HCV glycoproteins}

The topology of the transmembrane domain of $\mathrm{HCV}$ envelope glycoproteins has given rise to some controversy. Indeed the presence of a first hydrophobic stretch and a signal sequence function separated by charged residues in the transmembrane domains of E1 and E2 has suggested that they might be composed of two membrane spanning segments with the charged residues facing the cytosol (Charloteaux et al., 2002). This type of organization has been observed in the C-terminal region of the envelope glycoprotein E2 of the alphaviruses as well as for the envelope proteins of the flaviviruses (Op De Beeck 
et al., 2003; Strauss and Strauss, 1994; Zhang et al., 2003). However sequence analysis and data of alanine scanning insertion mutagenesis were in favor of a single spanning topology of E1 and E2 transmembrane domain (Cocquerel et al., 2000; Op De Beeck et al., 2000). A study of the topology of the transmembrane domains of HCV envelope proteins has been performed by determining the accessibility of their $\mathrm{N}$ - and $\mathrm{C}$-termini in selectively permeabilized cells (Cocquerel et al., 2002). This work has shown that before signal sequence cleavage at their C-terminus, the transmembrane domains form a hairpin structure (Fig. 1). However, after cleavage between E1 and E2 or between E2 and p7, the second C-terminal hydrophobic stretch is reoriented towards the cytosol, leading to the formation of a single membrane-spanning domain. Here again, the charged residues located in the middle of the transmembrane domains were shown to play a crucial role in their structural dynamics (Cocquerel et al., 2002).

\section{Role of HCV envelope glycoproteins in virus entry}

For most viruses, entry into the cytosol is a multistep process, during which the host cell assists the incoming virus. Viruses first attach themselves to components of the plasma membrane, which they use as non-specific attachment factors or as specific cell surface receptors. Viral attachment is mediated by the binding of a protein present at the surface of the virion to a molecule on the cell surface acting as a virus receptor. The envelope glycoprotein complex E1E2 is the viral component thought to be present at the surface of HCV particles and it is therefore the obvious candidate ligand for cellular receptors. Receptor binding can activate cellular endocytic pathways through which viruses are internalized in endosomes. When they reach the appropriate intracellular location, viruses are activated for penetration by cellular signals and make their way through the membrane of the endosome, or through the plasma membrane for those that do not enter by endocytosis. Enveloped viruses fuse their lipid envelope with the plasma membrane or the membrane of an endosome, resulting in the release of the nucleocapsid into the cytosol.

\section{Models to study HCV entry}

In the absence of a robust cell culture system to amplify $\mathrm{HCV}$, several models have been developed to study HCV entry. In a first approach, a soluble form of HCV glycoprotein E2 has been used to identify cell surface proteins potentially involved in $\mathrm{HCV}$ entry (Pileri et al., 1998; Rosa et al., 1996). Although this approach is potentially interesting in protein-protein interactions studies, it cannot be used to study the entire entry process. In addition, as discussed above, due to their cooperative role in folding, both glycoproteins need to be co-expressed to analyze their functional properties. To study the role of E1E2 envelope glycoproteins in $\mathrm{HCV}$ entry, several surrogate models of $\mathrm{HCV}$ particles have therefore been developed. As a first approach, virus-like particles have been produced in insect cells infected by a recombinant baculovirus containing the cDNA of $\mathrm{HCV}$ structural proteins (Baumert et al., 1998). However these particles are not infectious and they are retained in an intracellular compartment. It is therefore difficult to evaluate how close these virus-like particles are to native virion. In addition, due to the absence of infectivity, these particles cannot be used to study the fusion process. Another approach to study HCV entry has been to produce virosomes by incorporating E1E2 heterodimers into liposomes (Lambot et al., 2002). These virosomes can be used to study the interactions between E1E2 heterodimers and cell surface receptors. However, it has not been shown whether the envelope glycoproteins incorporated into these liposomes can induce fusion.

Other models have been based on pseudotyping of viral vectors. The first model that has been developed was based on vesicular stomatitis virus (VSV) pseudotyped with modified E1 and/or E2 glycoproteins (Lagging et al., 1998; Matsuura et al., 2001). In these particles, the transmembrane domains of HCV envelope glycoproteins have been replaced by the transmembrane domain and cytoplasmic tail of the VSV envelope glycoprotein G. This allows the export of HCV envelope glycoproteins to the cell surface (Takikawa et al., 2000). However, some doubts have been raised on the infectivity of such VSV pseudotyped particles (Buonocore et al., 2002). In addition, replacement of $\mathrm{HCV}$ envelope glycoproteins has been shown to alter their entry function (Hsu et al., 2003).

More recently, retroviruses have also been used to produce pseudotyped particles containing HCV envelope glycoproteins (Bartosch et al., 2003b; Drummer et al., 2003; Hsu et al., 2003). Murine leukemia virus (MLV) or human immunodeficiency virus (HIV) vectors were used. Retroviruses are indeed well known to be able to incorporate in their envelope a variety of cellular and viral glycoproteins (Ott, 1997; Sandrin et al., 2002). In addition, they can easily package and integrate genetic markers into host cell DNA (Negre et al., 2002). All these properties were exploited to produce viral pseudoparticles expressing E1E2 at their surface and packaging a reporter gene that allows the monitoring of viral infection. HCV pseudoparticles (HCVpp) are produced by transfecting 293T cells with three expression vectors encoding the E1E2 polyprotein, the retroviral core proteins and a packaging-competent retrovirus-derived genome containing a marker gene (Fig. 3). Because MLV and HIV are supposed to assemble at the plasma membrane and $\mathrm{HCV}$ glycoproteins are retained in the ER, a first approach has been to modify the transmembrane domains of $\mathrm{E} 1$ and E2 to re-address them at the plasma membrane (Hsu et al., 2003; Pohlmann et al., 2003). However pseudoparticles bearing such modified $\mathrm{HCV}$ envelope glycoproteins were not infectious. Surprisingly, in the absence of any modification of HCV envelope glycoproteins, infectious pseudoparticles were produced (Bartosch et al., 2003b; Drummer et al., 2003; Hsu et al., 2003). Interestingly, due to saturation of the ER retention machinery, the cells used to produce HCVpp were shown to express a small fraction of HCV envelope glycoproteins at the plasma membrane (Bartosch et al., 2003b; Drummer et al., 2003; Hsu et al., 2003; Op De Beeck et al., 2004). This accumulation at the plasma membrane might therefore be sufficient to incorporate native $\mathrm{HCV}$ envelope glycoproteins into retroviral pseudotyped particles. However, a recent study 


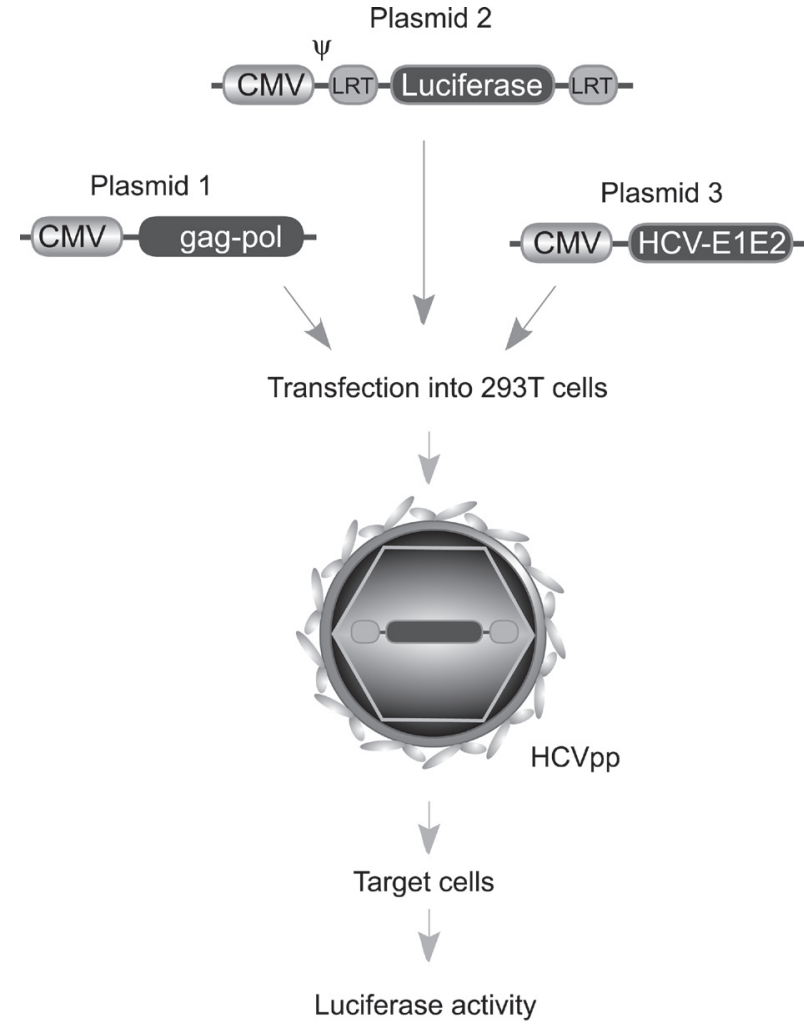

Fig. 3. Production of HCV pseudoparticles (HCVpp). For the production of HCVpp, human embryo kidney cells 293T are transfected with three expression vectors. The first vector encodes retroviral Gag and Pol proteins. Gag proteins are responsible for particle budding at the plasma membrane and RNA encapsidation via recognition of the specific retroviral encapsidation sequence $(\psi)$. The second vector harbors a $\psi$ sequence for encapsidation and encodes a reporter protein (Luciferase). This vector also contains retroviral sequences that are necessary for the reverse transcription of genomic RNA into proviral DNA and for integration of the proviral DNA in the host genomic DNA by the retroviral protein Pol encoded by the first vector. The third vector encodes HCV envelope glycoproteins, which are responsible for the cell tropism and fusion of HCVpp with the target cell membrane. HCVpp contain Gag, Pol, E1 and E2 proteins as well as the RNA encoding the luciferase protein. Infectivity of HCVpp is evaluated by measuring the amount of luciferase expressed in target cells.

suggests that HCVpp might assemble in multivesicular bodies (Sandrin et al., 2005). Interestingly, accumulation of HCV envelope glycoproteins at the plasma membrane has been exploited to develop a cell-cell fusion assay for HCV (Kobayashi et al., 2006).

The data that have been accumulated on HCVpp strongly suggest that they mimic the early steps of HCV infection. Indeed, they exhibit a preferential tropism for hepatic cells and they are specifically neutralized by anti-E2 monoclonal antibodies as well as sera from HCV-infected patients (Bartosch et al., 2003b; Hsu et al., 2003; Op De Beeck et al., 2004). These HCVpp therefore represent the best tool available to study functional HCV envelope glycoproteins. An analysis of the glycoproteins associated with HCVpp has shown the heterogeneous nature of E1 and E2 incorporated into HCVpp (Flint et al., 2004). This highlights the difficulty in identifying forms of the HCV glycoproteins that initiate infection. However, characterization of HCVpp envelope glycoproteins with conformation-sensitive neutralizing monoclonal antibodies has shown that the functional unit is a noncovalent
E1E2 heterodimer (Op De Beeck et al., 2004). In addition, coexpression of both envelope glycoproteins has been shown to be necessary to produce infectious pseudoparticles (Bartosch et al., 2003b), confirming that only the E1E2 heterodimer is functional.

More recently, several laboratories have reported the development of a cell-culture system that allows a relatively efficient amplification of $\mathrm{HCV}$ (HCVcc) (Lindenbach et al., 2005; Wakita et al., 2005; Zhong et al., 2005). This system is based on the transfection of the human hepatoma cell line Huh-7 with genomic HCV RNA of the genotype 2a JFH1 strain cloned from an individual with fulminant hepatitis. In order to allow comparative studies between different HCV strains, chimeric genomes encoding the structural proteins from different genotypes and the non-structural proteins from the JFH1 isolate have also been made (Pietschmann et al., 2006). The HCVcc system allows, for the first time, the study of the complete viral cycle life and is very helpful to confirm the data generated with HCVpp.

\section{HCV receptors}

As a first approach to identify potential HCV receptor(s), a soluble form of HCV glycoprotein E2 has been used. This allowed the identification of the CD81 tetraspanin (Levy and Shoham, 2005) as a putative receptor for HCV (Pileri et al., 1998). A very similar approach identified the scavenger receptor class B type I (SR-BI) (Scarselli et al., 2002), a high-density lipoprotein (HDL)-binding molecule (Connelly and Williams, 2004), and the mannose binding lectins DC-SIGN and L-SIGN (van Kooyk and Geijtenbeek, 2003) as additional candidate receptors for HCV (Gardner et al., 2003; Lozach et al., 2003; Ludwig et al., 2004; Pohlmann et al., 2003). Heparan sulfate has also been shown to interact with $\mathrm{HCV}$ glycoprotein E2, suggesting that this type of molecule can play a role in HCV entry (Barth et al., 2003). An approach using virus-like particles produced in insect cells has led to the identification of the asialoglycoprotein receptor as another candidate receptor for HCV (Saunier et al., 2003). Very recently, claudin-1, a tight junction protein highly expressed in the liver, has been shown to be essential for HCV entry (M.J. Evans, T von Hahn, A.J. Syder, T. Hatziioannou, J.A. McKeating P. Bieniasz, C.M. Rice, $13^{\text {th }}$ International Meeting on Hepatitis $C$ virus and Related Viruses, Cairns, Australia, 27-31 August 2006). Finally, because of the physical association of HCV with low- or very-low-density lipoproteins (LDL or VLDL) in serum, the LDL receptor has also been proposed as another candidate receptor for HCV (Agnello et al., 1999; Monazahian et al., 1999).

A number of cell-surface molecules bind viral envelope glycoproteins without mediating entry, and validation of a viral receptor or co-receptor requires proof that the putative receptor is necessary for infection. This is not easy for HCV due to the absence of a robust cell culture system to amplify this virus. The development of $\mathrm{HCVpp}$ and more recently of HCVcc has allowed to further investigate the role of candidate receptors in virus entry. Among all the candidate receptors, CD81, Claudin-1 and SR-BI have been shown to play a direct role in HCVpp entry. Indeed, antibodies directed against CD81 or SR$\mathrm{BI}$ as well as siRNA targeting CD81 or Claudin-1 reduce HCVpp or HCVcc infectivity (Bartosch et al., 2003b; 
Bartosch et al., 2003c; Cormier et al., 2004b; Hsu et al., 2003; Lavillette et al., 2005b; Lindenbach et al., 2005; Wakita et al., 2005; Zhang et al., 2004a; Zhong et al., 2005) (M.J. Evans, T von Hahn, A.J. Syder, T. Hatziioannou, J.A. McKeating P. Bieniasz, C.M. Rice, $13^{\text {th }}$ International Meeting on Hepatitis $C$ virus and Related Viruses, Cairns, Australia, 27-31 August 2006). Furthermore, it has been shown that CD81 and Claudin-1 are acting during a postattachment step (Koutsoudakis et al., 2006) (M.J. Evans, T von Hahn, A.J. Syder, T. Hatziioannou, J.A. McKeating P. Bieniasz, C.M. Rice, 13th International Meeting on Hepatitis C Virus and Related Viruses, Cairns, Australia, 27-31 August 2006). Although SR-BI has been shown to be involved in $\mathrm{HCV}$ entry, it might probably not work as a classical receptor. Recently, it has been shown that HDL, the natural ligand of SR-BI, enhance HCV entry (Bartosch et al., 2005; Meunier et al., 2005; Voisset et al., 2005). In addition, this HDL-mediated enhancement of $\mathrm{HCV}$ entry involves the lipid transfer activity of SR-BI (Bartosch et al., 2005; Voisset et al., 2005). It is worth noting that the presence of HDL leads to an attenuation anti-HCV neutralizing antibodies (Dreux et al., 2006; Voisset et al., 2006).

Interactions between viral envelope glycoproteins and potential receptors can have other consequences than virus entry. It has been shown that intracellular interaction between HCV envelope glycoproteins and CD81 can lead to secretion of exosomes containing E1 and E2 glycoproteins (Masciopinto et al., 2004). Interestingly, a soluble form of E2 is also able to bind CD81 at the surface of natural killer cells, and this interaction inhibits cytotoxicity and cytokine production by these cells (Crotta et al., 2002; Tseng and Klimpel, 2002). Binding of a soluble form of E2 can also provide a co-stimulatory signal for $T$ cells (Soldaini et al., 2003; Wack et al., 2001), activate naïve B lymphocytes (Rosa et al., 2005) and upregulate matrix metalloproteinase-2 in human hepatic stellate cells (Mazzocca et al., 2005). It remains however to be determined whether HCV glycoprotein expressed in the context of native particles will have the same effects on cell functions.

HCVpp have also been used to investigate the role of other candidate receptors in HCV entry. HCVpp as well as native $\mathrm{HCV}$ particles have been shown to bind to cells expressing L-SIGN and DC-SIGN (Gardner et al., 2003; Lozach et al., 2004; Pohlmann et al., 2003). Although these molecules are not expressed on hepatocytes, HCV interactions with L-SIGN and DC-SIGN may contribute to establishment or persistence of infection both by the capture and delivery of virus to the liver and by modulating dendritic cell functions as recently suggested (Cormier et al., 2004a; Lozach et al., 2004). Competition studies suggest that interaction of $\mathrm{HCV} c \mathrm{c}$ with cell surface glycosaminoglycans play a role in efficient infection of Huh-7 cells (Koutsoudakis et al., 2006). Finally, there is no clear evidence that the LDL receptor is a major receptor for HCVpp (Bartosch et al., 2003b).

\section{Functional regions of HCV envelope glycoproteins} HCVpp have been used to investigate the functional role of some regions of $\mathrm{HCV}$ envelope glycoproteins in virus entry. Mutagenesis studies of the transmembrane domains of HCV envelope glycoproteins have shown that some mutations can affect the entry function of HCVpp without alteration in the biogenesis of E1E2 heterodimer and their incorporation into HCVpp (Ciczora et al., 2005). This suggests that in addition to their role in E1E2 heterodimerization, the transmembrane domains of $\mathrm{HCV}$ glycoproteins might play a role in coordinating protein reorganization for the fusion process to occur.

Studies of E2-CD81 interactions and identification of epitopes recognized by antibodies that inhibit these interactions suggest that the CD81-binding region consists of discrete segments of E2 that are rearranged within the same domain during E2 folding (Clayton et al., 2002; Flint et al., 1999a; Forns et al., 2000a; Hsu et al., 2003; Owsianka et al., 2001; Yagnik et al., 2000). Interestingly, E2 residues critical for CD81 binding have recently been identified by site-directed mutagenesis (Drummer et al., 2006; Owsianka et al., 2006). They include amino acids W420, W437, L438, L441, F442, Y527, W529, G530 and D535.

Besides the CD81 binding region, the hypervariable region 1 (HVR1) (Weiner et al., 1991), a 27-amino-acid long segment found at the N-terminus of E2 (Fig. 2), has also been suggested to play a role in cell attachment (Penin et al., 2001; Scarselli et al., 2002). This region evolves rapidly in infected individuals, suggesting that it is under strong immune pressure (reviewed in Mondelli et al., 2003). Although an HCV clone lacking HVR1 was shown to be infectious in chimpanzee, this mutant virus was attenuated, suggesting that HVR1 plays a facilitating role in HCV infectivity (Forns et al., 2000b). In addition, deletion of HVR1 reduces HCVpp infectivity (Bartosch et al., 2003c) and abolishes HDL-mediated enhancement of HCVpp infectivity (Voisset et al., 2005). Despite strong amino acid sequence variability related to strong pressure towards change, the chemicophysical properties and conformation of HVR1 are highly conserved, and HVR1 is a globally basic stretch, with basic residues located at specific sequence positions. Functional studies of HCVpp containing mutations in HVR1 indicate that infectivity increases with the number of basic residues in HVR1 (Callens et al., 2005). In addition, a shift in position of some charged residues modulates infectivity. These data suggest that HVR1 is a region involved in interaction with a host molecule involved in HCV entry.

HCV envelope glycoproteins are highly glycosylated and some maturation of these glycans has been observed on HCV envelope glycoproteins associated with HCVpp (Flint et al., 2004; Lozach et al., 2004; Op De Beeck et al., 2004). Mutation of some glycosylation sites in HCV envelope glycoproteins can reduce or abolish HCVpp infectivity without apparently affecting folding and incorporation of the glycoproteins into the particles (Goffard et al., 2005). N-linked glycans at position N2 and N4 of E2 have indeed been shown to be essential for the entry functions of $\mathrm{HCV}$ envelope glycoproteins (Fig. 2). In addition, some other glycans (N2 of E1 and N5, N6 and N11 of E2) can also modulate HCVpp entry. Further studies will be necessary to determine whether these mutations affect receptor binding or the fusion properties of HCV envelope glycoproteins. Interestingly, it has recently been shown that the interaction of lectin 
cyanovirin- $\mathrm{N}$ with $\mathrm{HCV}$ envelope protein glycans leads to inhibition of HCV entry by inhibiting CD81-E2 interaction (Helle et al., 2006).

\section{Mechanisms of HCV entry}

Virus attachment to receptors initiates a series of events that lead to virus entry. For enveloped viruses, the entry process is controlled by viral surface glycoproteins that undergo triggered conformational changes from a metastable state to a lower energy state. This structural change leads to the exposure of a buried functional element, named the fusion peptide and is believed to provide the energy required for the merging of the lipid bilayers (reviewed in Colman and Lawrence, 2003). Until very recently, viral fusion proteins have been shown to fall into two different structural classes designated as class I and II (reviewed in Earp et al., 2005). Class I fusion proteins possess $\mathrm{N}$-terminal or $\mathrm{N}$-proximal fusion peptides, and they are synthesized as a precursor that is cleaved into two subunits by host cell proteases. In some cases (e.g. influenza HA), the two subunits remain associated through a disulfide bond, whereas in others (e.g. HIV Env) the two subunits remain associated through noncovalent interactions. The proteolytic processing event creates the metastable state of the fusion protein (Colman and Lawrence, 2003). In their native metastable conformation, class I fusion proteins form trimeric spikes at the surface of the virions with the fusion subunit being highly helical. Upon a fusion trigger event (receptor binding at the cell surface or low $\mathrm{pH}$ in endosomes), the trimeric proteins transiently form an extended conformation allowing the hydrophobic fusion peptide to insert into the target membrane. Protein refolding leads then to the formation of very stable trimeric structures in which both the $\mathrm{N}$ proximal fusion peptide and the C-proximal membrane anchor are juxtaposed at the same end to allow virus and cell membrane connection and hemifusion (reviewed in Colman and Lawrence, 2003).

Class II viral fusion proteins have a completely different structure. They are predominantly non-helical, instead having a beta-sheet type structure; they are not cleaved during biosynthesis; and they possess an internal fusion peptide with a loop conformation (reviewed in Earp et al., 2005). The proteins are oriented parallel to the membrane, and they have a three-domain architecture with domain I beginning at the N-terminus, domain II containing the internal fusion loop, and domain III being at the C-terminus. In addition, class II fusion proteins are synthesized as a complex with a second membrane glycoprotein (prM for flaviviruses; pE2 for alphaviruses). Newly synthesized $E$ and prM proteins of the tickborne encephalitis virus associate to form noncovalent heterodimers (Fig. 4) that are incorporated into immature virions by budding into the ER lumen (Allison et al., 1995; Mackenzie and Westaway, 2001). These particles are then transported through the secretory pathway and shortly before release from the cell, the activation of the fusogenic potential occurs by the cleavage of the accessory protein prM by a cellular furin protease in the trans-Golgi network (Stadler et al., 1997). After prM cleavage, the E protein exists as a metastable homodimer at the virion surface. The ectodomains of the dimer are orientated antiparallel
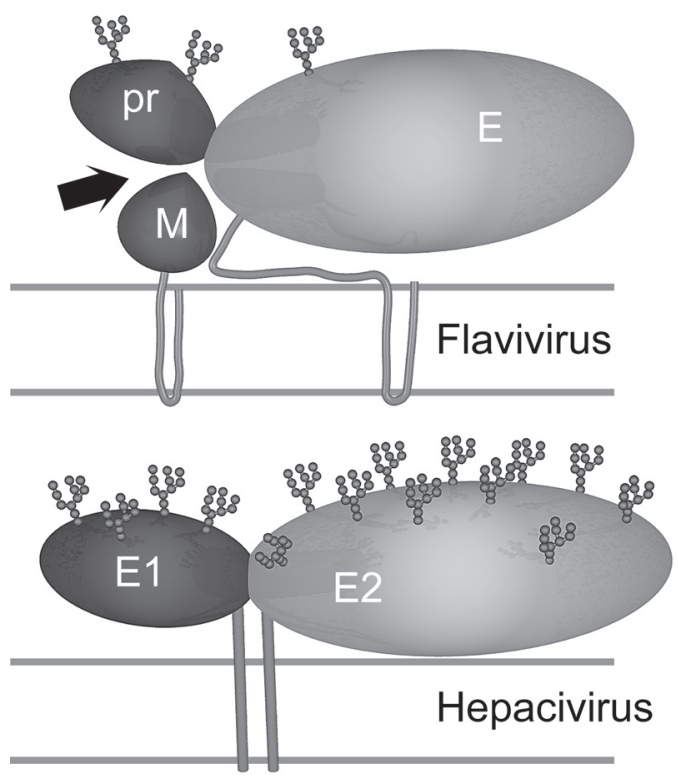

Fig. 4. Comparison of flavivirus and hepacivirus envelope proteins. In the Flaviviridae family, class II fusion proteins (depicted in light grey) have been described in the flaviviruses ( $E$ protein of tick born encephalitis and dengue viruses). They are synthesized as a complex with a second membrane glycoprotein (depicted in dark grey). Shortly before release from the cell, activation of the fusogenic potential occurs by cleavage of the accessory protein (arrow). HCV envelope glycoproteins are supposed to belong to the class II fusion proteins, but contrary to flaviviruses, HCV envelope proteins are highly glycosylated and are not matured by a cellular endoprotease during their transport through the secretory pathway.

to one another (Modis et al., 2003; Rey et al., 1995). The architecture of the alphavirus Semliki Forest virus spike is similar to that of tick-borne encephalitis virus $E$, but in this case, the metastable oligomer is a heterodimer of the fusion protein E1 and the companion protein E2 with an associated small protein E3 (Modis et al., 2003; Rey et al., 1995). In addition, contrary to flaviviruses, alphaviruses have been shown to bud from the plasma membrane.

It is worth noting that the notion of class I and II fusion proteins is more complex than previously thought. Indeed, the reported crystal structures of herpes simplex virus glycoprotein B and glycoprotein $\mathrm{G}$ of vesicular stomatitis virus have revealed multidomain trimers with features characteristic of both class I and class II fusion proteins (Heldwein et al., 2006; Roche et al., 2006).

Both alphaviruses and flaviviruses enter target cells by receptor-mediated endocytosis. The receptor recognition function is carried by the fusion protein itself for the flaviviruses (E) and by the companion protein (E2) for the alphaviruses. Exposure to the acidic $\mathrm{pH}$ of the endosomes triggers a major conformational change of the envelope involving dissociation of the native homodimer (for flaviviruses) or heterodimer (for alphaviruses) and the irreversible formation of homotrimers of the fusion proteins (Earp et al., 2005; Mukhopadhyay et al., 2005).

Based on its classification in the Flaviviridae family, $\mathrm{HCV}$ envelope has been proposed to contain a class II fusion protein (Yagnik et al., 2000). As found in the case of alphaviruses and flaviviruses, HCVpp and HCVcc entry depends on acidic $\mathrm{pH}$ and on clathrin-mediated endocytosis (Bartosch et al., 2003c; Blanchard et al., 2006; 
Hsu et al., 2003; Koutsoudakis et al., 2006; Tscherne et al., 2006). Moreover, it has recently been shown that after internalization in clathrin-coated vesicles, HCVpp entry required the delivery to early endosomes (Meertens et al., 2006). However, we still do not know if the acidic $\mathrm{pH}$ of endosomes is sufficient to activate E1E2 and induce fusion or if other endosomal factors are required. Indeed, although acidic $\mathrm{pH}$ can induce HCVpp-liposome fusion without any preliminary priming event (Lavillette et al., 2006), it has been reported that HCVcc and HCVpp infection at the plasma membrane induced by a $\mathrm{pH}$ drop was very inefficient (Meertens et al., 2006; Tscherne et al., 2006). Characterization of the route of HCV entry needs further investigations. Contrary to what is observed for other class II envelope proteins, there is no evidence that $\mathrm{HCV}$ envelope glycoproteins are matured by a cellular endoprotease during their transport through the secretory pathway (Op De Beeck et al., 2004). In addition, HCV envelope glycoproteins are highly glycosylated, whereas other described class II envelope proteins contain a very low number of glycans (Fig. 4). Interestingly, some of the glycans present on HCV envelope glycoproteins are involved in controlling HCV entry (Goffard et al., 2005).

There remains some controversy on the identity of HCV fusion protein. It has been proposed that E1 might be a good candidate because sequence analyses suggest that it might contain a putative fusion peptide in its ectodomain (Flint et al., 1999b; Garry and Dash, 2003). On the other hand, potential structural homology with other class II fusion proteins suggests that E2 could be the fusion protein (Yagnik et al., 2000). Mutagenesis studies in the putative fusion peptides of the envelope glycoproteins associated with HCVpp as described for the flavivirus envelope protein E (Allison et al., 2001), should be helpful for further characterization of HCV fusion protein. In addition, a high-resolution structure of $\mathrm{HCV}$ envelope glycoproteins would also help understanding the fusion mechanism of the virus.

\section{Inhibition of HCV envelope glycoprotein functions by neutralizing antibodies}

Because they are exposed at the surface of the virion, the envelope proteins are targets of neutralizing antibodies. These antibodies block a viral infection by inhibiting virion binding or membrane fusion. Understanding the mechanisms of neutralization needs therefore a good knowledge of the mechanism of entry. The role of neutralizing antibodies in $\mathrm{HCV}$ infection and disease progression remained unclear for a long time, largely because of the lack of assays to measure and quantify their activity. Previous experiments showed that serum from a chronically infected patient could neutralize HCV infectivity in a chimpanzee model, giving evidence for antibody-mediated neutralization of HCV (Farci et al., 1994). Neutralizing antibodies could also be identified by their ability to prevent HCV replication in a lymphoid cell line (Shimizu et al., 1994; Shimizu et al., 1996).

The development of HCVpp and HCVcc offers the possibility to study HCV neutralization with defined sequences of $\mathrm{HCV}$ envelope glycoproteins, and the use of HCVpp and HCVcc in neutralization studies has been validated. As determined with $\mathrm{HCVpp}$, it seems that the majority of chronically infected patients have crossreactive neutralizing antibodies (Logvinoff et al., 2004; Meunier et al., 2005). In contrast, neutralizing antibodies have not been detected in several cases of acute resolving infection (Logvinoff et al., 2004; Meunier et al., 2005), and the detection of neutralizing antibodies in acutely infected individuals did not seem to be associated with viral clearance (Logvinoff et al., 2004). However, another study has shown in some patients a progressive emergence of a relatively strong neutralizing response in correlation with a decrease in viremia (Lavillette et al., 2005a). Further investigations on a large number of acutely infected patients will be necessary to determine the role of neutralizing antibodies in controlling $\mathrm{HCV}$ infections. Interestingly, it has been observed that HCVpp and HCVcc infectivity is enhanced by human sera, and this enhancement of infectivity can partly mask the presence of neutralizing antibodies (Dreux et al., 2006; Lavillette et al., 2005a; Meunier et al., 2005; Voisset et al., 2006). In addition, HDL have been identified as the component responsible for serum-mediated enhancement of infectivity (Bartosch et al., 2005; Meunier et al., 2005; Voisset et al., 2005) and have been shown to attenuate neutralization of $\mathrm{HCV}$ entry by monoclonal and $\mathrm{HCV}$ patient-derived antibodies (Dreux et al., 2006; Voisset et al., 2006). Attenuation of neutralization by HDL could be explained by a more rapid kinetic of HDL-facilitation of HCVpp entry compared to virus neutralization (Voisset et al., 2006).

For a long time, the HVR-1 sequence of E2 has been proposed to be a major target for neutralizing antibodies (Farci et al., 1996; Kato et al., 1993). However, data obtained with the HCVpp model indicate that neutralizing epitopes located outside of HVR1 also exist (Bartosch et al., 2003a). Interestingly, characterization of HCVpp with monoclonal antibodies has allowed the identification of conformation-dependent and -independent neutralizing epitopes outside of HVR1 (Fig. 2) (Bartosch et al., 2003b; Hsu etal., 2003; Kecketal., 2004; OpDe Beecketal., 2004). Conformation-dependent human monoclonal antibodies have also led to the identification of three immunogenic domains in E2 with neutralizing antibodies being restricted to two of these domains (Keck et al., 2004). Whether E2 domains identified with these monoclonal antibodies are similar to the antigenic structural and functional domains of the envelope protein $\mathrm{E}$ of the flaviviruses (Rey et al., 1995) remains to be determined.

\section{Conclusion and future directions}

Studies of the biogenesis of HCV envelope glycoproteins have shown the pivotal role of the transmembrane domains in the assembly of a noncovalent E1E2 heterodimer in the ER. The HCVpp model has allowed the investigation of the role of E1E2 heterodimer in virus entry, the identification of functional regions in HCV envelope glycoproteins and the validation of potential receptors. The recent development of the HCVcc system is an additional tool to validate the data generated with HCVpp. Entry is an essential step in the life cycle of a virus, which can potentially be blocked by neutralizing antibodies or antiviral drugs that target the envelope proteins of the virus. Understanding the viral and cellular 
components involved in HCV invasion into the host cell, combined with a comprehension of the mechanisms that govern this process, should therefore open the possibility of developing new therapeutic approaches, as shown with cyanovirin-N (Helle et al., 2006).

In addition to their role in virus entry, HCV envelope glycoproteins are also supposed to be involved in other steps of HCV life cycle, e.g. particle assembly. Studying other functions of HCV glycoproteins in the context of its life cycle is now possible with the development of the $\mathrm{HCV} c \mathrm{system}$. Understanding the role of HCV envelope glycoproteins in virus assembly will be a major goal in the coming years. Finally, obtaining a high-resolution structure of HCV envelope glycoproteins will also be essential to understand the fusion mechanism of this virus.

\section{Acknowledgments}

We thank Sophana Ung for preparing the illustrations. Our research was supported by EU grant QLRT-2000-01120 and QLRT-2001-01329 and grants from the "Agence Nationale de Recherche sur le Sida et les hépatites virales" (ANRS), INSERM "ATC-Hépatite C" and the "Association pour la Recherche sur le Cancer" (ARC). JD is an international scholar of the Howard Hughes Medical Institute.

\section{References}

Agnello, V., Abel, G., Elfahal, M., Knight, G.B., and Zhang, Q.-X. (1999). Hepatitis C virus and other flaviviridae viruses enter cells via low density lipoprotein receptor. Proc. Natl. Acad. Sci. USA 96, 12766-12771.

Allison, S.L., Schalich, J., Stiasny, K., Mandl, C.W., and Heinz, F.X. (2001). Mutational evidence for an internal fusion peptide in flavivirus envelope protein E. J. Virol. 75, 4268-4275.

Allison, S.L., Schalich, J., Stiasny, K., Mandl, C.W., Kunz, C., and Heinz, F.X. (1995). Oligomeric rearrangement of tick-borne encephalitis virus envelope proteins induced by an acidic pH. J. Virol. 69, 695-700.

Barth, H., Schafer, C., Adah, M.I., Zhang, F., Linhardt, R.J., Toyoda, H., Kinoshita-Toyoda, A., Toida, T., Van Kuppevelt, T.H., Depla, E., et al. (2003). Cellular binding of hepatitis $\mathrm{C}$ virus envelope glycoprotein E2 requires cell surface heparan sulfate. J. Biol. Chem. 278, 41003-41012.

Bartosch, B., Bukh, J., Meunier, J.C., Granier, C., Engle, R.E., Blackwelder, W.C., Emerson, S.U., Cosset, F.L., and Purcell, R.H. (2003a). In vitro assay for neutralizing antibody to hepatitis $C$ virus: evidence for broadly conserved neutralization epitopes. Proc. Natl. Acad. Sci. USA 100, 14199-14204.

Bartosch, B., Dubuisson, J., and Cosset, F.L. (2003b). Infectious hepatitis $\mathrm{C}$ pseudo-particles containing functional E1E2 envelope protein complexes. J. Exp. Med. 197, 633-642.

Bartosch, B., Verney, G., Dreux, M., Donot, P., Morice, Y., Penin, F., Pawlotsky, J.M., Lavillette, D., and Cosset, F.L. (2005). An interplay between the hyper-variable region 1 of the HCV E2 glycoprotein, the scavenger receptor $\mathrm{BI}$ and $\mathrm{HDL}$ promotes both enhancement of infection and protection against neutralizing antibodies. J. Virol. 79, 8217-8229.
Bartosch, B., Vitelli, A., Granier, C., Goujon, C., Dubuisson, J., Pascale, S., Scarselli, E., Cortese, R., Nicosia, A., and Cosset, F.L. (2003c). Cell entry of hepatitis C virus requires a set of co-receptors that include the CD81 tetraspanin and the SR-B1 scavenger receptor. J. Biol. Chem. 278, 41624-41630.

Baumert, T.F., Ito, S., Wong, D.T., and Liang, T.J. (1998). Hepatitis C virus structural proteins assemble into viruslike particles in insect cells. J. Virol. 72, 38273836.

Blanchard, E., Belouzard, S., Goueslain, L., Wakita, T., Dubuisson, J., Wychowski, C., and Rouille, Y. (2006). Hepatitis C virus entry depends on clathrin-mediated endocytosis. J. Virol. 80, 6964-6972.

Blight, K.J., Kolykhalov, A.A., and Rice, C.M. (2000). Efficient initiation of HCV RNA replication in cell culture. Science 290, 1972-1974.

Brazzoli, M., Helenius, A., Foung, S.K., Houghton, M., Abrignani, S., and Merola, M. (2005). Folding and dimerization of hepatitis $\mathrm{C}$ virus $\mathrm{E} 1$ and $\mathrm{E} 2$ glycoproteins in stably transfected $\mathrm{CHO}$ cells. Virology 332, 438453.

Buonocore, L., Blight, K.J., Rice, C.M., and Rose, J.K. (2002). Characterization of vesicular stomatitis virus recombinants that express and incorporate high levels of hepatitis C virus glycoproteins. J. Virol. 76, 68656872.

Callens, N., Ciczora, Y., Bartosch, B., Vu-Dac, N., Cosset, F.L., Pawlotsky, J.M., Penin, F., and Dubuisson, J. (2005). Basic residues in hypervariable region 1 of hepatitis $\mathrm{C}$ virus envelope glycoprotein e2 contribute to virus entry. J. Virol. 79, 15331-15341.

Carrère-Kremer, S., Montpellier, C., Lorenzo, L., Brulin, B., Cocquerel, L., Belouzard, S., Penin, F., and Dubuisson, J. (2004). Regulation of hepatitis C virus polyprotein processing by signal peptidase involves structural determinants at the $\mathrm{p} 7$ sequence junctions. J. Biol. Chem. 279, 41384-41392.

Carrère-Kremer, S., Montpellier-Pala, C., Cocquerel, L., Wychowski, C., Penin, F., and Dubuisson, J. (2002). Subcellular localization and topology of the p7 polypeptide of hepatitis C virus. J. Virol. 76, 37203730.

Charloteaux, B., Lins, L., Moereels, H., and Brasseur, R. (2002). Analysis of the C-terminal membrane anchor domains of hepatitis $C$ virus glycoproteins $E 1$ and E2: toward a topological model. J. Virol. 76, 1944-1958.

Choukhi, A., Ung, S., Wychowski, C., and Dubuisson, J. (1998). Involvement of endoplasmic reticulum chaperones in folding of hepatitis $\mathrm{C}$ virus glycoproteins. J. Virol. 72, 3851-3858.

Ciczora, Y., Callens, N., Montpellier, C., Bartosch, B., Cosset, F.L., Op De Beeck, A., and Dubuisson, J. (2005). Contribution of the charged residues of HCV glycoprotein E2 transmembrane domain to the functions of E1E2 heterodimer. J. Gen. Virol. 86, 2793-2798.

Clayton, R.F., Owsianka, A., Aitken, J., Graham, S., Bhella, D., and Patel, A. H. (2002). Analysis of antigenicity and topology of E2 glycoprotein present on recombinant hepatitis C virus-like particles. J. Virol. 76, 7672-7682.

Cocquerel, L., Duvet, S., Meunier, J.-C., Pillez, A., Cacan, R., Wychowski, C., and Dubuisson, J. (1999). The 
transmembrane domain of hepatitis $\mathrm{C}$ virus glycoprotein $\mathrm{E} 1$ is a signal for static retention in the endoplasmic reticulum. J. Virol. 73, 2641-2649.

Cocquerel, L., Kuo, C.-C., Dubuisson, J., and Levy, S. (2003a). CD81-dependent binding of Hepatitis C virus E1E2 heterodimers. J. Virol. 77, 10677-10683.

Cocquerel, L., Meunier, J.-C., Pillez, A., Wychowski, C., and Dubuisson, J. (1998). A retention signal necessary and sufficient for endoplasmic reticulum localization maps to the transmembrane domain of hepatitis $C$ virus glycoprotein E2. J. Virol. 72, 2183-2191.

Cocquerel, L., Meunier, J.C., Op De Beeck, A., Bonte, D., Wychowski, C., and Dubuisson, J. (2001). Coexpression of hepatitis $C$ virus envelope proteins $E 1$ and $E 2$ in cis improves the stability of membrane insertion of E2. J. Gen. Virol. 82, 1629-1635.

Cocquerel, L., Op de Beeck, A., Lambot, M., Roussel, J., Delgrange, D., Pillez, A., Wychowski, C., Penin, F., and Dubuisson, J. (2002). Topologic changes in the Transmembrane Domains of Hepatitis C Virus Envelope Glycoproteins. EMBO J. 21, 2893-2902.

Cocquerel, L., Quinn, E.R., Flint, M., Hadlock, K.G., Foung, S.K., and Levy, S. (2003b). Recognition of native hepatitis $\mathrm{C}$ virus E1E2 heterodimers by a human monoclonal antibody. J. Virol. 77, 1604-1609.

Cocquerel, L., Wychowski, C., Minner, F., Penin, F., and Dubuisson, J. (2000). Charged residues in the transmembrane domains of Hepatitis C virus glycoproteins play a key role in the processing, subcellular localization and assembly of these envelope proteins. J. Virol. 74, 3623-3633.

Colman, P.M., and Lawrence, M.C. (2003). The structural biology of type I viral membrane fusion. Nat. Rev. Mol. Cell Biol. 4, 309-319.

Connelly, M.A., and Williams, D.L. (2004). Scavenger receptor Bl: a scavenger receptor with a mission to transport high density lipoprotein lipids. Curr. Opin. Lipidol. 15, 287-295.

Cormier, E.G., Durso, R.J., Tsamis, F., Boussemart, L., Manix, C., Olson, W.C., Gardner, J.P., and Dragic, T. (2004a). L-SIGN (CD209L) and DC-SIGN (CD209) mediate transinfection of liver cells by hepatitis $C$ virus. Proc. Natl. Acad. Sci. USA 101, 14067-14072.

Cormier, E.G., Tsamis, F., Kajumo, F., Durso, R.J., Gardner, J.P., and Dragic, T. (2004b). CD81 is an entry coreceptor for hepatitis C virus. Proc. Natl. Acad. Sci. USA 101, 7270-7274.

Crotta, S., Stilla, A., Wack, A., D'Andrea, A., Nuti, S., D'Oro, U., Mosca, M., Filliponi, F., Brunetto, R.M., Bonino, F., et al. (2002). Inhibition of natural killer cells through engagement of CD81 by the major hepatitis C virus envelope protein. J. Exp. Med. 195, 35-41.

Deleersnyder, V., Pillez, A., Wychowski, C., Blight, K., Xu, J., Hahn, Y.S., Rice, C.M., and Dubuisson, J. (1997). Formation of native hepatitis $\mathrm{C}$ virus glycoprotein complexes. J. Virol. 71, 697-704.

Dreux, M., Pietschmann, T., Granier, C., Voisset, C., Ricard-Blum, S., Mangeot, P.E., Keck, Z., Foung, S., Vu-Dac, N., Dubuisson, J., et al. (2006). High density lipoprotein inhibits hepatitis C virus-neutralizing antibodies by stimulating cell entry via activation of the scavenger receptor BI. J. Biol. Chem. 281, 1828518295.

Drummer, H.E., Boo, I., Maerz, A.L., and Poumbourios, P. (2006). A conserved Gly436-Trp-Leu-Ala-Gly-LeuPhe-Tyr motif in hepatitis $C$ virus glycoprotein $E 2$ is a determinant of CD81 binding and viral entry. J. Virol. 80, 7844-7853.

Drummer, H.E., Maerz, A., and Poumbourios, P. (2003). Cell surface expression of functional hepatitis $C$ virus E1 and E2 glycoproteins. FEBS Lett. 546, 385-390.

Drummer, H.E., and Poumbourios, P. (2004). Hepatitis C virus glycoprotein E2 contains a membrane-proximal heptad repeat sequence that is essential for E1E2 glycoprotein heterodimerization and viral entry. J. Biol. Chem. 279, 30066-30072.

Dubuisson, J. (2000). Folding, assembly and subcellular localization of HCV glycoproteins. Curr. Top. Microbiol. Immunol. 242, 135-148.

Dubuisson, J., Duvet, S., Meunier, J.C., Op De Beeck, A., Cacan, R., Wychowski, C., and Cocquerel, L. (2000). Glycosylation of the hepatitis $C$ virus envelope protein $\mathrm{E} 1$ is dependent on the presence of a downstream sequence on the viral polyprotein. J. Biol. Chem. 275, 30605-30609.

Dubuisson, J., Hsu, H.H., Cheung, R.C., Greenberg, H.B., Russell, D.G., and Rice, C.M. (1994). Formation and intracellular localization of hepatitis $C$ virus envelope glycoprotein complexes expressed by recombinant vaccinia and Sindbis viruses. J. Virol. 68, 6147-6160.

Dubuisson, J., Penin, F., and Moradpour, D. (2002). Interaction of hepatitis C virus proteins with host cell membranes and lipids. Trends Cell Biol. 12, 517-523.

Dubuisson, J., and Rice, C.M. (1996). Hepatitis C virus glycoprotein folding: disulfide bond formation and association with calnexin. J. Virol. 70, 778-786.

Duvet, S., Cocquerel, L., Pillez, A., Cacan, R., Verbert, A., Moradpour, D., Wychowski, C., and Dubuisson, J. (1998). Hepatitis C virus glycoprotein complex localization in the endoplasmic reticulum involves a determinant for retention and not retrieval. J. Biol. Chem. 273, 32088-32095.

Duvet, S., Op De Beeck, A., Cocquerel, L., Wychowski, C., Cacan, R., and Dubuisson, J. (2002). Glycosylation of the hepatitis $\mathrm{C}$ virus envelope protein E1 occurs posttranslationally in a mannosylphosphoryldolicholdeficient $\mathrm{CHO}$ mutant cell line. Glycobiology 12, 95101.

Earp, L.J., Delos, S.E., Park, H.E., and White, J.M. (2005). The many mechanisms of viral membrane fusion proteins. Curr. Top. Microbiol. Immunol. 285, 25-66.

Farci, P., Alter, H.J., Wong, D.C., Miller, R.H., Govindarajan, S., Engle, R., Shapiro, M., and Purcell, R.H. (1994). Prevention of hepatitis $\mathrm{C}$ virus infection in chimpanzees after antibody- mediated in vitro neutralization. Proc. Natl. Acad. Sci. USA 91, 7792-7796.

Farci, P., Shimoda, A., Wong, D., Cabezon, T., De Gioannis, D., Strazzera, A., Shimizu, Y., Shapiro, M., Alter, H.J., and Purcell, R.H. (1996). Prevention of hepatitis C virus infection in chimpanzees by hyperimmune serum against the hypervariable region 1 of the envelope 2 protein. Proc. Natl. Acad. Sci. USA 93, 15394-15399. 
Flint, M., Logvinoff, C., Rice, C.M., and McKeating, J.A. (2004). Characterization of infectious retroviral pseudotype particles bearing hepatitis $C$ virus glycoproteins. J. Virol. 78, 6875-6882.

Flint, M., Maidens, C., Loomis-Price, L.D., Shotton, C., Dubuisson, J., Monk, P., Higginbottom, A., Levy, S., and McKeating, J.A. (1999a). Characterization of hepatitis C virus E2 glycoprotein interaction with a putative cellular receptor, CD81. J. Virol. 73, 6235-6244.

Flint, M., Thomas, J.M., Maidens, C.M., Shotton, C., Levy, S., Barclay, W.S., and McKeating, J.A. (1999b). Functional analysis of cell surface-expressed hepatitis C virus E2 glycoprotein. J. Virol. 73, 6782-6790.

Forns, X., Allander, T., Rohwer-Nutter, P., and Bukh, J. (2000a). Characterization of modified hepatitis $C$ virus E2 proteins expressed on the cell surface. Virology 274, 75-85.

Forns, X., Thimme, R., Govindarajan, S., Emerson, S.U., Purcell, R.H., Chisari, F.V., and Bukh, J. (2000b). Hepatitis $C$ virus lacking the hypervariable region 1 of the second envelope protein is infectious and causes acute resolving or persistent infection in chimpanzees. Proc. Natl. Acad. Sci. USA 97, 13318-13323.

Gardner, J.P., Durso, R.J., Arrigale, R.R., Donovan, G.P., Maddon, P.J., Dragic, T., and Olson, W.C. (2003). LSIGN (CD 209L) is a liver-specific capture receptor for hepatitis C virus. Proc. Natl. Acad. Sci. USA 100, 4498-4503.

Garry, R.F., and Dash, S. (2003). Proteomics computational analyses suggest that hepatitis $C$ virus $E 1$ and pestivirus E2 envelope glycoproteins are truncated class II fusion proteins. Virology 307, 255-265.

Gavel, Y., and von Heijne, G. (1990). Sequence differences between glycosylated and non-glycosylated Asn-X-Thr/ Ser acceptor sites: implications for protein engineering. Protein Eng. 3, 433-442.

Goffard, A., Callens, N., Bartosch, B., Wychowski, C., Cosset, F.L., Montpellier-Pala, C., and Dubuisson, J. (2005). Role of N-linked glycans in the functions of hepatitis $\mathrm{C}$ virus envelope glycoproteins. J. Virol. 79, 8400-8409.

Goffard, A., and Dubuisson, J. (2003). Glycosylation of hepatitis $\mathrm{C}$ virus envelope proteins. Biochimie 85, 295301.

Grakoui, A., Wychowski, C., Lin, C., Feinstone, S.M., and Rice, C.M. (1993). Expression and identification of hepatitis $\mathrm{C}$ virus polyprotein cleavage products. J. Virol. 67, 1385-1395.

Griffin, S.D., Beales, L.P., Clarke, D.S., Worsfold, O., Evans, S.D., Jaeger, J., Harris, M.P., and Rowlands, D.J. (2003). The $p 7$ protein of hepatitis $C$ virus forms an ion channel that is blocked by the antiviral drug, Amantadine. FEBS Lett. 535, 34-38.

Griffin, S.D., Harvey, R., Clarke, D.S., Barclay, W.S., Harris, M., and Rowlands, D.J. (2004). A conserved basic loop in hepatitis $C$ virus $p 7$ protein is required for amantadine-sensitive ion channel activity in mammalian cells but is dispensable for localization to mitochondria. J. Gen. Virol. 85, 451-461.

Hebert, D.N., Zhang, J.X., Chen, W., Foellmer, B., and Helenius, A. (1997). The number and location of glycans on influenza hemagglutinin determine folding and association with calnexin and calreticulin. J. Cell Biol. 139, 613-623.

Heldwein, E.E., Lou, H., Bender, F.C., Cohen, G.H., Eisenberg, R.J., and Harrison, S.C. (2006). Crystal structure of glycoprotein B from herpes simplex virus 1. Science 313, 217-220.

Helle, F., Wychowski, C., Vu-Dac, N., Gustafson, K.R., Voisset, C., and Dubuisson, J. (2006). Cyanovirin-N inhibits hepatitis $C$ virus entry by binding to envelope protein glycans. J. Biol. Chem. 281, 25177-25183.

Hsu, M., Zhang, J., Flint, M., Logvinoff, C., Cheng-Mayer, C., Rice, C.M., and McKeating, J.A. (2003). Hepatitis C virus glycoproteins mediate $\mathrm{pH}$-dependent cell entry of pseudotyped retroviral particles. Proc. Natl. Acad. Sci. USA 100, 7271-7276.

Imperiali, B., and O'Connor, S.E. (1999). Effect of Nlinked glycosylation on glycopeptide and glycoprotein structure. Curr. Opin. Chem. Biol. 3, 643-649.

Isherwood, B.J., and Patel, A.H. (2005). Analysis of the processing and transmembrane topology of the E2p7 protein of hepatitis C virus. J. Gen. Virol. 86, 667-676.

Kato, N., Sekiya, H., Ootsuyama, Y., Nakazawa, T., Hijikata, M., Ohkoshi, S., and Shimotohno, K. (1993). Humoral immune response to hypervariable region 1 of the putative envelope glycoprotein (gp70) of hepatitis C virus. J. Virol. 67, 3923-3930.

Keck, Z.Y., Op De Beeck, A., Hadlock, K.G., Xia, J., Li, T.K., Dubuisson, J., and Foung, S.K. (2004). Hepatitis $\mathrm{C}$ virus $\mathrm{E} 2$ has three immunogenic domains containing conformational epitopes with distinct properties and biological functions. J. Virol. 78, 9224-9232.

Kobayashi, M., Bennett, M.C., Bercot, T., and Singh, I.R. (2006). Functional analysis of hepatitis $C$ virus envelope proteins, using a cell-cell fusion assay. J. Virol. 80, 1817-1825.

Kornfeld, R., and Kornfeld, S. (1985). Assembly of asparagine-linked oligosaccharides. Annu. Rev. Biochem. 54, 631-664.

Koutsoudakis, G., Kaul, A., Steinmann, E., Kallis, S., Lohmann, V., Pietschmann, T., and Bartenschlager, R. (2006). Characterization of the early steps of hepatitis $\mathrm{C}$ virus infection by using luciferase reporter viruses. J. Virol. 80, 5308-5320.

Lagging, L.M., Meyer, K., Owens, R.J., and Ray, R. (1998). Functional role of hepatitis C virus chimeric glycoproteins in the infectivity of pseudotyped virus. J. Virol. 72, 3539-3546.

Lambot, M., Fretier, S., Op De Beeck, A., Quatannens, B., Lestavel, S., Clavey, V., and Dubuisson, J. (2002). Reconstitution of hepatitis C virus envelope glycoproteins into liposomes as a surrogate model to study virus attachment. J. Biol. Chem. 277, 2062520630.

Lavillette, D., Bartosch, B., Nourrisson, D., Verney, G., Cosset, F.L., Penin, F., and Pecheur, E.I. (2006). Hepatitis C virus glycoproteins mediate low $\mathrm{pH}$ dependent membrane fusion with liposomes. J. Biol. Chem. 281, 3909-3917.

Lavillette, D., Morice, Y., Germanidis, G., Donot, P., Soulier, A., Pagkalos, E., Sakellariou, G., Intrator, L., Bartosch, B., Pawlotsky, J.M., and Cosset, F.L. (2005a). Human serum facilitates hepatitis $C$ virus infection, and 
neutralizing responses inversely correlate with viral replication kinetics at the acute phase of hepatitis $\mathrm{C}$ Virus infection. J. Virol. 79, 6023-6034.

Lavillette, D., Tarr, A.W., Voisset, C., Donot, P., Bartosch, B., Bain, C., Patel, A.H., Dubuisson, J., Ball, J.K., and Cosset, F.L. (2005b). Characterization of host-range and cell entry properties of hepatitis $C$ virus of major genotypes and subtypes. Hepatology 41, 265-274.

Levy, S., and Shoham, T. (2005). The tetraspanin web modulates immune-signalling complexes. Nat. Rev. Immunol. 5, 136-148.

Lin, C., Lindenbach, B.D., Pragai, B.M., McCourt, D.W., and Rice, C.M. (1994). Processing in the hepatitis C virus E2-NS2 region: identification of $\mathrm{p} 7$ and two distinct E2-specific products with different $\mathrm{C}$ termini. J. Virol. 68, 5063-5073.

Lindenbach, B.D., Evans, M.J., Syder, A.J., Wolk, B., Tellinghuisen, T.L., Liu, C.C., Maruyama, T., Hynes, R.O., Burton, D.R., McKeating, J.A., and Rice, C.M. (2005). Complete replication of hepatitis $C$ virus in cell culture. Science 309, 623-626.

Lindenbach, B.D., and Rice, C.M. (2005). Unravelling hepatitis $\mathrm{C}$ virus replication from genome to function. Nature 436, 933-938.

Logvinoff, C., Major, M.E., Oldach, D., Heyward, S., Talal, A., Balfe, P., Feinstone, S.M., Alter, H., Rice, C.M., and McKeating, J.A. (2004). Neutralizing antibody response during acute and chronic hepatitis $C$ virus infection. Proc. Natl. Acad. Sci. USA 101, 10149-10154.

Lohmann, V., Körner, F., Koch, J.-O., Herian, U., Theilmann, L., and Bartenschlager, R. (1999). Replication of subgenomic hepatitis $C$ virus RNAs in a hepatoma cell line. Science 285, 110-113.

Lozach, P.Y., Amara, A., Bartosch, B., Virelizier, J.L., Arenzana-Seisdedos, F., Cosset, F.L., and Altmeyer, R. (2004). C-type Lectins L-SIGN and DC-SIGN capture and transmit infectious hepatitis $C$ virus pseudotype particles. J. Biol. Chem. 279, 32035-32045.

Lozach, P.Y., Lortat-Jacob, H., De Lacroix De Lavalette, A., Staropoli, I., Foung, S., Amara, A., Houles, C., Fieschi, F., Schwartz, Virelizier, J., et al. (2003). DCSIGN and L-SIGN are high-affinity binding receptors for hepatitis C Virus glycoprotein E2. J. Biol. Chem. 278, 20358-20366.

Ludwig, I.S., Lekkerkerker, A.N., Depla, E., Bosman, F., Musters, R.J., Depraetere, S., van Kooyk, Y., and Geijtenbeek, T.B. (2004). Hepatitis C virus targets DCSIGN and L-SIGN to escape lysosomal degradation. J. Virol. 78, 8322-8332.

Mackenzie, J.M., and Westaway, E.G. (2001). Assembly and maturation of the flavivirus kunjin virus appear to occur in the rough endoplasmic reticulum and along the secretory pathway, respectively. J. Virol. 75, 1078710799.

Masciopinto, F., Giovani, C., Campagnoli, S., GalliStampino, L., Colombatto, P., Brunetto, M., Yen, T.S., Houghton, M., Pileri, P., and Abrignani, S. (2004). Association of hepatitis $C$ virus envelope proteins with exosomes. Eur. J. Immunol. 34, 2834-2842.

Matsuura, Y., Tani, H., Suzuki, K., Kimura-Someya, T., Suzuki, R., Aizaki, H., Ishii, K., Moriishi, K., Robison, C.S., Whitt, M.A., and Miyamura, T. (2001).
Characterization of pseudotype VSV possessing HCV envelope proteins. Virology 286, 263-275.

Mazzocca, A., Sciammetta, S.C., Carloni, V., Cosmi, L., Annunziato, F., Harada, T., Abrignani, S., and Pinzani, M. (2005). Binding of hepatitis C virus envelope protein E2 to CD81 up-regulates matrix metalloproteinase2 in human hepatic stellate cells. J. Biol. Chem. 280, 11329-11339.

McLauchlan, J., Lemberg, M.K., Hope, R.G., and Martoglio, B. (2002). Intramembrane proteolysis promotes trafficking of hepatitis $\mathrm{C}$ virus core protein to lipid droplets. EMBO J. 21, 3980-3988.

Meertens, L., Bertaux, C., and Dragic, T. (2006). Hepatitis $C$ Virus entry requires a critical post-internalization step and delivery to early endosomes via clathrin coated vesicles. J. Virol., in press.

Merola, M., Brazzoli, M., Cocchiarella, F., Heile, J.M., Helenius, A., Weiner, A.J., Houghton, M., and Abrignani, S. (2001). Folding of hepatitis $C$ virus E1 glycoprotein in a cell-free system. J. Virol. 75, 11205-11217.

Meunier, J.-C., Fournillier, A., Choukhi, A., Cahour, A., Cocquerel, L., Dubuisson, J., and Wychowski, C. (1999). Analysis of the glycosylation sites of hepatitis $C$ virus (HCV) glycoprotein E1 and the influence of E1 glycans on the formation of the HCV glycoprotein complex. J. Gen. Virol. 80, 887-896.

Meunier, J.C., Engle, R.E., Faulk, K., Zhao, M., Bartosch, B., Alter, H., Emerson, S.U., Cosset, F.L., Purcell, R.H., and Bukh, J. (2005). Evidence for cross-genotype neutralization of hepatitis $C$ virus pseudo-particles and enhancement of infectivity by apolipoprotein C1. Proc. Natl. Acad. Sci. USA 102, 4560-4565.

Michalak, J.-P., Wychowski, C., Choukhi, A., Meunier, J.-C., Ung, S., Rice, C.M., and Dubuisson, J. (1997). Characterization of truncated forms of hepatitis $\mathrm{C}$ virus glycoproteins. J. Gen. Virol. 78, 2299-2306.

Mizushima, H., Hijikata, M., Asabe, S.-I., Hirota, M., Kimura, K., and Shimotohno, K. (1994). Two hepatitis C virus glycoprotein $\mathrm{E} 2$ products with different $\mathrm{C}$ termini. J. Virol. 68, 6215-6222.

Modis, Y., Ogata, S., Clements, D., and Harrison, S.C. (2003). A ligand-binding pocket in the dengue virus envelope glycoprotein. Proc. Natl. Acad. Sci. USA 100, 6986-6991.

Monazahian, M., Bohme, I., Bonk, S., Koch, A., Scholz, C., Grethe, S., and Thomssen, R. (1999). Low density lipoprotein receptor as a candidate receptor for hepatitis C virus. J. Med. Virol. 57, 223-229.

Mondelli, M.U., Cerino, A., Meola, A., and Nicosia, A. (2003). Variability or conservation of hepatitis C virus hypervariable region 1? Implications for immune responses. J. Biosci. 28, 305-310.

Mottola, G., Jourdan, N., Castaldo, G., Malagolini, N., Lahm, A., Serafini-Cessi, F., Migliaccio, G., and Bonatti, S. (2000). A new determinant of endoplasmic reticulum localization is contained in the juxtamembrane region of the ectodomain of hepatitis $\mathrm{C}$ virus glycoprotein $\mathrm{E} 1$. J. Biol. Chem. 275, 24070-24079.

Mukhopadhyay, S., Kuhn, R.J., and Rossmann, M.G. (2005). A structural perspective of the flavivirus life cycle. Nat. Rev. Microbiol. 3, 13-22. 
Nakano, I., Fukuda, Y., Katano, Y., and Hayakawa, T. (1999). Conformational epitopes detected by crossreactive antibodies to envelope 2 glycoprotein of the hepatitis C virus. J. Infect. Dis. 180, 1328-1333.

Negre, D., Duisit, G., Mangeot, P.E., Moullier, P., Darlix, J.L., and Cosset, F.L. (2002). Lentiviral vectors derived from simian immunodeficiency virus. Curr. Top. Microbiol. Immunol. 261, 53-74.

Ohuchi, M., Ohuchi, R., Feldmann, A., and Klenk, H.D. (1997a). Regulation of receptor binding affinity of influenza virus hemagglutinin by its carbohydrate moiety. J. Virol. 71, 8377-8384.

Ohuchi, R., Ohuchi, M., Garten, W., and Klenk, H.D. (1997b). Oligosaccharides in the stem region maintain the influenza virus hemagglutinin in the metastable form required for fusion activity. J. Virol. 71, 3719-3725.

Op De Beeck, A., Cocquerel, L., and Dubuisson, J. (2001). Biogenesis of hepatitis $C$ virus envelope glycoproteins. J. Gen. Virol. 82, 2589-2595.

Op De Beeck, A., and Dubuisson, J. (2003). Another putative receptor for hepatitis $\mathrm{C}$ virus. Hepatology 37 , 705-707.

Op De Beeck, A., Molenkamp, R., Caron, M., Ben Younes, A., Bredenbeek, P., and Dubuisson, J. (2003). Role of the transmembrane domains of prM and $E$ proteins in the formation of yellow fever virus envelope. J. Virol. 77, 813-820.

Op De Beeck, A., Montserret, R., Duvet, S., Cocquerel, L., Cacan, R., Barberot, B., Le Maire, M., Penin, F., and Dubuisson, J. (2000). Role of the transmembrane domains of hepatitis $C$ virus envelope proteins $E 1$ and E2 in the assembly of the noncovalent E1E2 heterodimer. J. Biol. Chem. 275, 31428-31437.

Op De Beeck, A., Voisset, C., Bartosch, B., Ciczora, Y., Cocquerel, L., Keck, Z., Foung, S., Cosset, F.L., and Dubuisson, J. (2004). Characterization of functional hepatitis C virus envelope glycoproteins. J. Virol. 78, 2994-3002.

Ott, D.E. (1997). Cellular proteins in HIV virions. Rev. Med. Virol. 7, 167-180.

Owsianka, A., Clayton, R.F., Loomis-Price, L.D., McKeating, J.A., and Patel, A.H. (2001). Functional analysis of hepatitis $\mathrm{C}$ virus $\mathrm{E} 2$ glycoproteins and viruslike particles reveals structural dissimilarities between different forms of E2. J. Gen. Virol. 82, 1877-1883.

Owsianka, A.M., Timms, J.M., Tarr, A.W., Brown, R.J., Hickling, T.P., Szwejk, A., Bienkowska-Szewczyk, K., Thomson, B.J., Patel, A.H., and Ball, J.K. (2006). Identification of conserved residues in the E2 envelope glycoprotein of the hepatitis $\mathrm{C}$ virus that are critical for CD81 binding. J. Virol. 80, 8695-8704.

Patel, J., Patel, A.H., and McLauchlan, J. (2001). The transmembrane domain of the hepatitis $C$ virus E2 glycoprotein is required for correct folding of the E1 glycoprotein and native complex formation. Virology 279, 58-68.

Pavlovic, D., Neville, D.C., Argaud, O., Blumberg, B., Dwek, R.A., Fischer, W.B., and Zitzmann, N. (2003). The hepatitis $C$ virus $p 7$ protein forms an ion channel that is inhibited by long-alkyl-chain iminosugar derivatives. Proc. Natl. Acad. Sci. USA 100, 6104-6108.
Penin, F., Combet, C., Germanidis, G., Frainais, P.O., Deléage, G., and Pawlotsky, J.M. (2001). Conservation of the conformation and positive charges of hepatitis $C$ virus E2 envelope glycoprotein hypervariable region 1 points to a role in cell attachment. J. Virol. 75, 57035710.

Penin, F., Dubuisson, J., Rey, F.A., Moradpour, D., and Pawlotsky, J.M. (2004). Structural biology of hepatitis C virus. Hepatology 39, 5-19.

Pietschmann, T., Kaul, A., Koutsoudakis, G., Shavinskaya, A., Kallis, S., Steinmann, E., Abid, K., Negro, F., Dreux, M., Cosset, F.L., and Bartenschlager, R. (2006). Construction and characterization of infectious intragenotypic and intergenotypic hepatitis $C$ virus chimeras. Proc. Natl. Acad. Sci. USA 103, 7408-7413.

Pileri, P., Uematsu, Y., Campagnoli, S., Galli, G., Falugi, F., Petracca, R., Weiner, A. J., Houghton, M., Rosa, D., Grandi, G., and Abrignani, S. (1998). Binding of hepatitis C virus to CD81. Science 282, 938-941.

Pohlmann, S., Zhang, J., Baribaud, F., Chen, Z., Leslie, G.J., Lin, G., Granelli-Piperno, A., Doms, R.W., Rice, C.M., and McKeating, J.A. (2003). Hepatitis C virus glycoproteins interact with DC-SIGN and DC-SIGNR. J. Virol. 77, 4070-4080.

Premkumar, A., Wilson, L., Ewart, G.D., and Gage, P.W. (2004). Cation-selective ion channels formed by p7 of hepatitis $\mathrm{C}$ virus are blocked by hexamethylene amiloride. FEBS Lett. 557, 99-103.

Ralston, R., Thudium, K., Berger, K., Kuo, C., Gervase, B., Hall, J., Selby, M., Kuo, G., Houghton, M., and Choo, Q.-L. (1993). Characterization of hepatitis C virus envelope glycoprotein complexes expressed by recombinant vaccinia viruses. J. Virol. 67, 6753-6761.

Reed, K.E., and Rice, C.M. (2000). Overview of hepatitis $\mathrm{C}$ virus genome structure, polyprotein processing, and protein properties. Curr. Top. Microbiol. Immunol. 242, 55-84.

Rey, F.A., Heinz, F.X., Mandl, C., Kunz, C., and Harrison, S.C. (1995). The envelope glycoprotein from tick-borne encephalitis virus at 2 A resolution. Nature 375, 291298.

Roche, S., Bressanelli, S., Rey, F.A., and Gaudin, Y. (2006). Crystal structure of the low-pH form of the vesicular stomatitis virus glycoprotein G. Science 313, 187-191.

Rosa, D., Campagnoli, S., Moretto, C., Guenzi, E., Cousens, L., Chin, M., Dong, C., Weiner, A., Lau, J.Y.N., Choo, Q.-L., et al. (1996). A quantitative test to estimate neutralizing antibodies to the hepatitis $C$ virus: cytofluorimetric assessment of the envelope glycoprotein 2 binding to target cells. Proc. Natl. Acad. Sci. USA 93, 1759-1763.

Rosa, D., Saletti, G., De Gregorio, E., Zorat, F., Comar, C., D'Oro, U., Nuti, S., Houghton, M., Barnaba, V., Pozzato, G., and Abrignani, S. (2005). Activation of naive B lymphocytes via CD81, a pathogenetic mechanism for hepatitis C virus-associated B lymphocyte disorders. Proc. Natl. Acad. Sci. USA 102, 18544-18549.

Rouillé, Y., Helle, F., Delgrange, D., Roingeard, P., Voisset, C., Blanchard, E., Belouzard, S., McKeating, J., Patel, A. H., Maertens, G., et al. (2006). Subcellular localization of hepatitis $C$ virus structural proteins in a 
cell culture system that efficiently replicates the virus. J. Virol. 80, 2832-2841.

Sandrin, V., Boson, B., Salmon, P., Gay, W., Nègre, D., Le Grand, R., Trono, D., and Cosset, F.-L. (2002). Lentiviral vectors pseudotyped with a modified RD114 envelope glycoprotein show increased stability in sera and augmented transduction of primary lymphocytes and CD34+ cells derived from human and non-human primates. Blood 100, 823-832.

Sandrin, V., Boulanger, P., Penin, F., Granier, C., Cosset, F.L., and Bartosch, B. (2005). Assembly of functional hepatitis $C$ virus glycoproteins on infectious pseudoparticles occurs intracellularly and requires concomitant incorporation of E1 and E2 glycoproteins. J. Gen. Virol. 86, 3189-3199.

Santolini, E., Migliaccio, G., and La Monica, N. (1994). Biosynthesis and biochemical properties of the hepatitis C virus core protein. J. Virol. 68, 3631-3641.

Saunier, B., Triyatni, M., Ulianich, L., Maruvada, P., Yen, P., and Kohn, L.D. (2003). Role of the asialoglycoprotein receptor in binding and entry of hepatitis $C$ virus structural proteins in cultured human hepatocytes. J. Virol. 77, 546-559.

Scarselli, E., Ansuini, H., Cerino, R., Roccasecca, R.M., Acali, S., Filocamo, G., Traboni, C., Nicosia, A., Cortese, R., and Vitelli, A. (2002). The human scavenger receptor class B type I is a novel candidate receptor for the hepatitis C virus. EMBO J. 21, 5017-5025.

Selby, M.J., Glazer, E., Masiarz, F., and Houghton, M. (1994). Complex processing and protein:protein interactions in the E2:NS2 region of HCV. Virology 204, 114-122.

Shimizu, Y.K., Hijikata, M., Iwamoto, A., Alter, H.J., Purcell, R.H., and Yoshikura, H. (1994). Neutralizing antibodies against hepatitis $\mathrm{C}$ virus and the emergence of neutralization escape mutant viruses. J. Virol. 68, 1494-1500.

Shimizu, Y.K., Igarashi, H., Kiyohara, T., Cabezon, T., Farci, P., Purcell, R.H., and Yoshikura, H. (1996). A hyperimmune serum against a synthetic peptide corresponding to the hypervariable region 1 of hepatitis C virus can prevent viral infection in cell cultures. Virology 223, 409-412.

Silberstein, S., and Gilmore, R. (1996). Biochemistry, molecular biology, and genetics of the oligosaccharyltransferase. FASEB J. 10, 849-858.

Slater-Handshy, T., Droll, D.A., Fan, X., Di Bisceglie, A.M., and Chambers, T.J. (2004). HCV E2 glycoprotein: mutagenesis of $\mathrm{N}$-linked glycosylation sites and its effects on E2 expression and processing. Virology 319, 36-48.

Soldaini, E., Wack, A., D’Oro, U., Nuti, S., Ulivieri, C., Baldari, C.T., and Abrignani, S. (2003). T cell costimulation by the hepatitis $\mathrm{C}$ virus envelope protein E2 binding to CD81 is mediated by Lck. Eur. J. Immunol. 33, 455-464.

Stadler, K., Allison, S.L., Schalich, J., and Heinz, F.X. (1997). Proteolytic activation of tick-borne encephalitis virus by furin. J. Virol. 71, 8475-8481.

Strauss, J.H., and Strauss, E.G. (1994). The alphaviruses: gene expression, replication, and evolution. Microbiol. Rev. 58, 491-562.
Takikawa, S., Ishii, K., Aizaki, H., Suzuki, T., Asakura, H., Matsuura, Y., and Miyamura, T. (2000). Cell fusion activity of hepatitis $\mathrm{C}$ virus envelope proteins. J. Virol. 74, 5066-5074.

Trombetta, E.S., and Helenius, A. (1998). Lectins as chaperones in glycoprotein folding. Curr. Opin. Struct. Biol. 8, 587-592.

Tscherne, D.M., Jones, C.T., Evans, M.J., Lindenbach, B.D., McKeating, J.A., and Rice, C.M. (2006). Time- and temperature-dependent activation of hepatitis $C$ virus for low-pH-triggered entry. J. Virol. 80, 1734-1741.

Tseng, C.T., and Klimpel, G.R. (2002). Binding of the hepatitis $C$ virus envelope protein E2 to CD81 inhibits natural killer cell functions. J. Exp. Med. 195, 43-49.

van Kooyk, Y., and Geijtenbeek, T.B. (2003). DC-SIGN: escape mechanism for pathogens. Nat. Rev. Immunol. 3, 697-709.

Voisset, C., Callens, N., Blanchard, E., Op De Beeck, A., Dubuisson, J., and Vu-Dac, N. (2005). High density lipoproteins facilitate hepatitis $\mathrm{C}$ virus entry through the scavenger receptor class B type I. J. Biol. Chem. 280, 7793-7799.

Voisset, C., Op de Beeck, A., Horellou, P., Dreux, M., Gustot, T., Duverlie, G., Cosset, F.L., Vu-Dac, N., and Dubuisson, J. (2006). High-density lipoproteins reduce the neutralizing effect of hepatitis $\mathrm{C}$ virus (HCV)infected patient antibodies by promoting HCV entry. J. Gen. Virol. 87, 2577-2581.

von Messling, V., and Cattaneo, R. (2003). N-linked glycans with similar location in the fusion protein head modulate paramyxovirus fusion. J. Virol. 77, 1020210212.

Wack, A., Soldaini, E., Tseng, C., Nuti, S., Klimpel, G., and Abrignani, S. (2001). Binding of the hepatitis C virus envelope protein E2 to CD81 provides a costimulatory signal for human T cells. Eur. J. Immunol. 31, 166-175.

Wakita, T., Pietschmann, T., Kato, T., Date, T., Miyamoto, M., Zhao, Z., Murthy, K., Habermann, A., Krausslich, H.G., Mizokami, M., et al. (2005). Production of infectious hepatitis $\mathrm{C}$ virus in tissue culture from a cloned viral genome. Nat. Med. 11, 791-796.

Wei, X., Decker, J.M., Wang, S., Hui, H., Kappes, J.C., Wu, X., Salazar-Gonzalez, J.F., Salazar, M.G., Kilby, J.M., Saag, M.S., et al. (2003). Antibody neutralization and escape by HIV-1. Nature 422, 307-312.

Weiner, A.J., Brauer, R., Rosenblatt, J., Richman, K.H., Tung, J., Crarford, K., Bonino, F., Saracco, G., Choo, Q.-L., Houghton, M., and Han, J.H. (1991). Variable and hypervariable domains are found in the regions of $\mathrm{HCV}$ corresponding to the flavivirus envelope and NS1 proteins and the pestivirus envelope glycoproteins. Virology 180, 842-848.

Wormald, M.R., and Dwek, R.A. (1999). Glycoproteins: glycan presentation and protein-fold stability. Structure Fold Des. 7, R155-160.

Yagnik, A.T., Lahm, A., Meola, A., Roccasecca, R.M., Ercole, B.B., Nicosia, A., and Tramontano, A. (2000). A model for the hepatitis $C$ virus envelope glycoprotein E2. Proteins 40, 355-366.

Zhang, J., Randall, G., Higginbottom, A., Monk, P., Rice, C.M., and McKeating, J.A. (2004a). CD81 is required for 
hepatitis $\mathrm{C}$ virus glycoprotein-mediated viral infection. J. Virol. 78, 1448-1455.

Zhang, M., Gaschen, B., Blay, W., Foley, B., Haigwood, N., Kuiken, C., and Korber, B. (2004b). Tracking global patterns of $\mathrm{N}$-linked glycosylation site variation in highly variable viral glycoproteins: HIV, SIV, and HCV envelopes and influenza hemagglutinin. Glycobiology 14, 1229-1246.

Zhang, W., Chipman, P.R., Corver, J., Johnson, P.R., Zhang, Y., Mukhopadhyay, S., Baker, T.S., Strauss,
J.H., Rossmann, M.G., and Kuhn, R.J. (2003). Visualization of membrane protein domains by cryoelectron microscopy of dengue virus. Nat. Struct. Biol. 10, 907-912.

Zhong, J., Gastaminza, P., Cheng, G., Kapadia, S., Kato, T., Burton, D.R., Wieland, S.F., Uprichard, S.L., Wakita, T., and Chisari, F.V. (2005). Robust hepatitis C virus infection in vitro. Proc. Natl. Acad. Sci. USA 102, 92949299. 


\section{Further Reading}

Caister Academic Press is a leading academic publisher of advanced texts in microbiology, molecular biology and medical research. Full details of all our publications at caister.com

- MALDI-TOF Mass Spectrometry in Microbiology Edited by: M Kostrzewa, S Schubert (2016) www.caister.com/malditof

- Aspergillus and Penicillium in the Post-genomic Era Edited by: RP Vries, IB Gelber, MR Andersen (2016) www.caister.com/aspergillus2

- The Bacteriocins: Current Knowledge and Future Prospects Edited by: RL Dorit, SM Roy, MA Riley (2016)

www.caister.com/bacteriocins

- Omics in Plant Disease Resistance Edited by: V Bhadauria (2016) www.caister.com/opd

- Acidophiles: Life in Extremely Acidic Environments Edited by: R Quatrini, DB Johnson (2016) www.caister.com/acidophiles

- Climate Change and Microbial Ecology: Current Research and Future Trend

Edited by: J Marxsen (2016)

www.caister.com/climate

- Biofilms in Bioremediation: Current Research and Emerging Technologies

Edited by: G Lear (2016)

www.caister.com/biorem

- Microalgae: Current Research and Applications Edited by: MN Tsaloglou (2016) www.caister.com/microalgae

- Gas Plasma Sterilization in Microbiology: Theory, Applications, Pitfalls and New Perspectives Edited by: H Shintani, A Sakudo (2016) www.caister.com/gasplasma

- Virus Evolution: Current Research and Future Directions Edited by: SC Weaver, M Denison, M Roossinck, et al. (2016) www.caister.com/virusevol

- Arboviruses: Molecular Biology, Evolution and Control Edited by: N Vasilakis, DJ Gubler (2016) www.caister.com/arbo

- Shigella: Molecular and Cellular Biology Edited by: WD Picking, WL Picking (2016) www.caister.com/shigella

-Aquatic Biofilms: Ecology, Water Quality and Wastewater Treatment

Edited by: AM Romaní, H Guasch, MD Balaguer (2016)

www.caister.com/aquaticbiofilms

- Alphaviruses: Current Biology

Edited by: S Mahalingam, L Herrero, B Herring (2016)

www.caister.com/alpha

- Thermophilic Microorganisms

Edited by: F Li (2015)

www.caister.com/thermophile
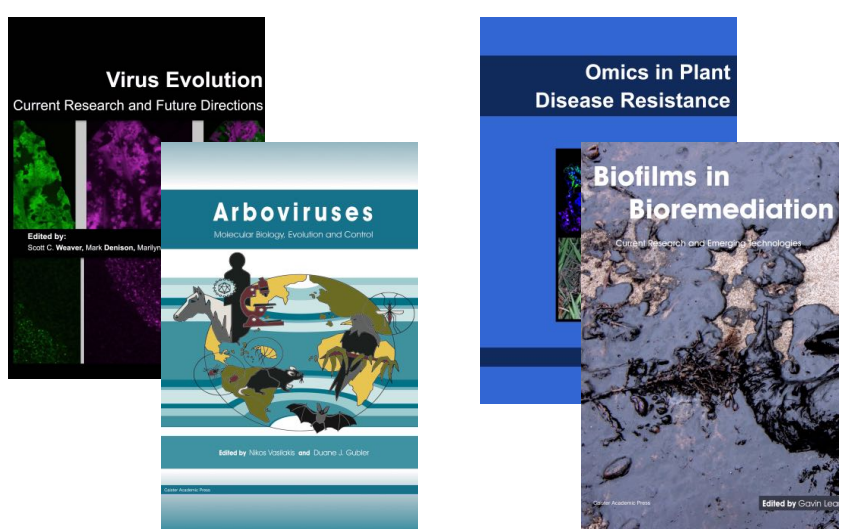
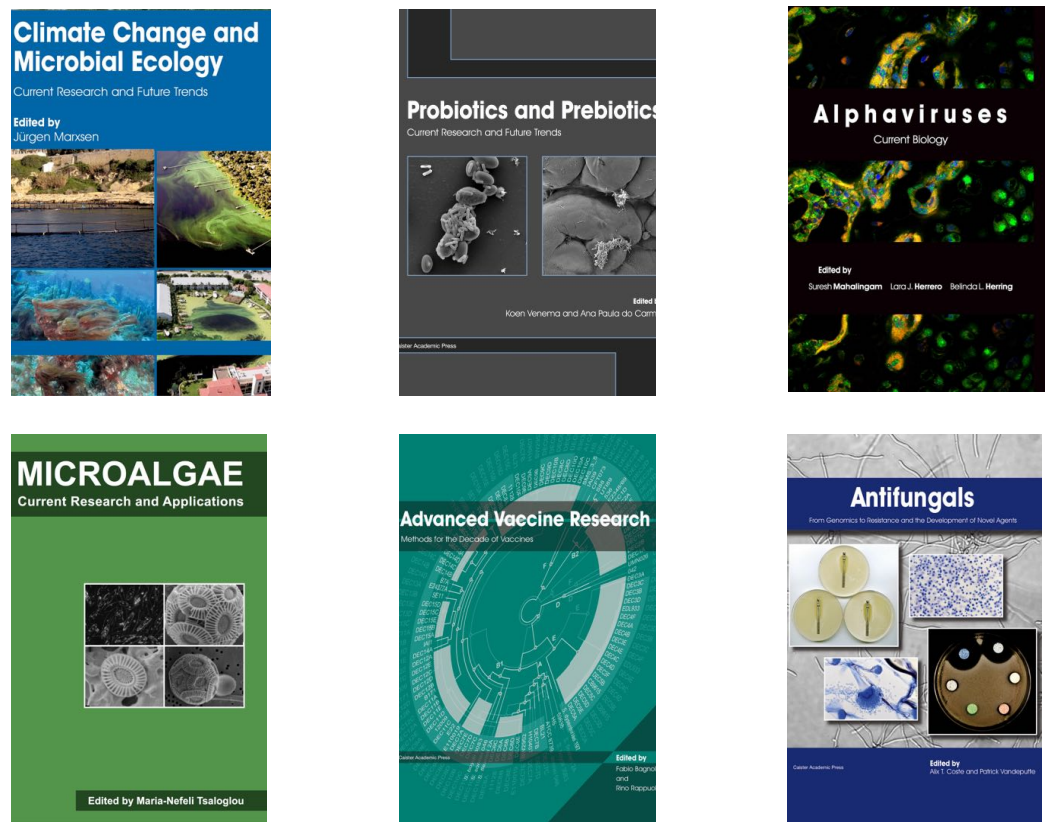

- Flow Cytometry in Microbiology: Technology and Applications Edited by: MG Wilkinson (2015) www.caister.com/flow

- Probiotics and Prebiotics: Current Research and Future Trends Edited by: K Venema, AP Carmo (2015) www.caister.com/probiotics

- Epigenetics: Current Research and Emerging Trends Edited by: BP Chadwick (2015) www.caister.com/epigenetics2015

- Corynebacterium glutamicum: From Systems Biology to Biotechnological Applications

Edited by: A Burkovski (2015)

www.caister.com/cory2

- Advanced Vaccine Research Methods for the Decade of Vaccines

Edited by: F Bagnoli, R Rappuoli (2015)

www.caister.com/vaccines

- Antifungals: From Genomics to Resistance and the Development of Novel Agents

Edited by: AT Coste, P Vandeputte (2015)

www.caister.com/antifungals

- Bacteria-Plant Interactions: Advanced Research and Future Trends Edited by: J Murillo, BA Vinatzer, RW Jackson, et al. (2015) www.caister.com/bacteria-plant

\section{- Aeromonas}

Edited by: J Graf (2015)

www.caister.com/aeromonas

- Antibiotics: Current Innovations and Future Trends

Edited by: S Sánchez, AL Demain (2015)

www.caister.com/antibiotics

- Leishmania: Current Biology and Contro Edited by: S Adak, R Datta (2015) www.caister.com/leish2

- Acanthamoeba: Biology and Pathogenesis (2nd edition) Author: NA Khan (2015)

www.caister.com/acanthamoeba2

- Microarrays: Current Technology, Innovations and Applications Edited by: Z He (2014)

www.caister.com/microarrays2

- Metagenomics of the Microbial Nitrogen Cycle: Theory, Methods and Applications

Edited by: D Marco (2014)

www.caister.com/n2 